\title{
Observation and Simulation of Meteorology and Surface Energy Components over the South China Sea in Summers of 2004 and 2006
}

\author{
Yung-Yao Lan ${ }^{1}$, Ben-Jei Tsuang ${ }^{1, *}$, Chia-Ying Tu ${ }^{2}$, Ting-Yu Wu ${ }^{1}$, \\ Yuan-Long Chen ${ }^{1}$, and Cheng-I Hsieh ${ }^{3}$ \\ ${ }^{1}$ Department of Environmental Engineering, National Chung Hsing University, Taichung, Taiwan, ROC \\ ${ }^{2}$ Taiwan Typhoon and Flood Research Institute, Taichung, Taiwan, ROC \\ ${ }^{3}$ Department of Bioenvironmental Systems Engineering, National Taiwan University, Taipei, Taiwan, ROC
}

Received 5 December 2008, accepted 7 April 2009

\begin{abstract}
Measurements of meteorological variables and surface energy components over the South China Sea (SCS) are compared with the NCEP-DOE AMIP-II reanalysis (NCEP2). The observations were conducted on a research vessel in the summers of 2004 and 2006. In addition, a one-column ocean model is used to simulate surface energy components and upper-level water temperatures (at 4 and $10 \mathrm{~m}$ depths). The simulated upper-level water temperatures agree well with the observations during the two cruises (OR1-728, OR1-802) with a root-mean-square difference (RMSD) smaller than $0.4 \mathrm{~K}$. The observations and the simulations show that the solar radiation (with a mean of $\left.\sim 200 \mathrm{~W} \mathrm{~m}^{-2}\right)$ is stronger than the latent heat flux $\left(\sim 160 \mathrm{~W} \mathrm{~m}^{-2}\right)$, and the latent heat flux is stronger than the sensible heat flux $\left(\sim 10 \mathrm{~W} \mathrm{~m}^{-2}\right)$ during both periods. Nonetheless, the magnitude of variability in heat flux caused by the sporadic wind is not seen in the reanalysis, it appears in the turbulent heat flux simulated by the model. The major differences between the model estimate and the NCEP2 reanalysis are the value of emissivity and the inclusion of diurnal cycles in key variables, with the value of NCEP2 for emissivity as 1 . The emissivity of this part of ocean is observed to be 0.96 with albedo at 0.07 .
\end{abstract}

Key words: South China Sea, Eddy covariance system, Radiation, Diurnal cycle, Sea surface temperature, One-column ocean model Citation: Lan, Y. Y., B. J. Tsuang, C. Y. Tu, T. Y. Wu, Y. L. Chen, and C. I. Hsieh, 2010: Observation and simulation of meteorology and surface energy components over the South China Sea in summers of 2004 and 2006. Terr. Atmos. Ocean. Sci., 21, 325-342, doi: 10.3319/TAO.2009.04.07.01(A)

\section{INTRODUCTION}

Oceans provide the largest surface area for energy exchanges between the atmosphere and Earth's surface and a sink for air pollutants. The South China Sea (SCS) is the largest marginal sea, encompassing an area from Singapore to the Strait of Taiwan of around $3500000 \mathrm{~km}^{2}$. More than half of the world's supertanker traffic passes through the region's waters. The SCS has depths that range from the shallowest coastal fringe to $5377 \mathrm{~m}$ in the Manila Trench (Morton and Blackmore 2001).

Numerous studies have shown that the SCS plays an important role for the evolution of the East-Asia summer monsoon (e.g., Lau et al. 1998; Wang et al. 2004; Shiau et al. 2008). Over the SCS, meteorological observations are quite sparse (Lin et al. 2002). Fortunately, global ocean surface

\footnotetext{
* Corresponding author

E-mail:tsuang@nchu.edu.tw
}

meteorological properties have been determined indirectly by satellites (Jo et al. 2004; Kawai et al. 2007; Zong et al. 2007) or through atmospheric model reanalysis (Hsu et al. 1997; Kanamitsu et al. 1997, 2002; Simmons and Gibson 2000; Li 2001). Nevertheless, evaluation on such products by comparison with observations over the ocean is limited (Angelucci et al. 1998; Tsuang et al. 2008a).

In order to study the spatial and temporal variations of the meteorology, surface energy components, and skin sea surface temperature (SSST) over the SCS, field campaigns were conducted in the summers of 2004 and 2006. During the field experiments, solar radiation, atmospheric radiation, and common meteorological variables were measured. In addition, a one-column ocean model was used to simulate the surface turbulent heat fluxes and SSST over the SCS. Our observed meteorological data and the calculated surface energy components are compared with the NCEP-DOE 
AMIP-II reanalysis (denoted as NCEP2) data (Kanamitsu et al. 2002). Note the reanalysis data have been used extensively as ground truth data for various purposes (e.g., Escoffier and Provost 1998; Wanninkhof et al. 2004; Feely et al. 2006; Mckinley et al. 2006; Midorikawa et al. 2006; Park et al. 2006; Zhang and Li 2008).

\section{SOUTH CHINA SEA EXPERIMENT}

Two research voyages were conducted on 15 August to 2 September 2004 (OR1-728) and 19 July to 2 August 2006 (OR1-802) over the SCS (Fig. 1). The research vessel, Ocean Researcher 1 (R/V OR1) was operated by the National Taiwan University with support from the Taiwan National Science Council, cruised over the SCS Basin. The routes of the cruises are shown in Fig. 1.

$\mathrm{R} / \mathrm{V}$ OR1 was equipped with several sets of instruments, including a navigation system, depth-sounder, ADCP (Acoustic Doppler Current Profilers) (King et al. 1996), and CTD (Conductivity Temperature Depth). Similar measurements were previously made in the SCS (Uu and Brankart 1997) and in the Taiwan Strait (Wang et al. 2003). On the ship, standard meteorological parameters as well as solar radiation, atmospheric radiation, and surface water temperature were measured (Fig. 2). Both air temperature and wind speeds were measured at $15 \mathrm{~m}$ above sea surface level (asl). Bulk surface water temperatures at 4,10 , and $15 \mathrm{~m}$ depths were measured by the CTD at each stop. Downward shortwave and longwave radiations were measured with an Eppley Pyranometer (PSP, EPLAB, USA) and an Eppley Pyrgeometer (PIR, EPLAB, USA) (Rozwadowska 2004), respectively. The observed wavelengths of the pyranometer are $0.3-3 \mu \mathrm{m}$ with an accuracy of $\pm 0.5 \%$, and the observed wavelengths of the pyrgeometer are $3-50 \mu \mathrm{m}$ with an accuracy of $\pm 1 \%$. All the radiation sensors were mounted on a mast at $7 \mathrm{~m}$ asl with an arm of $2 \mathrm{~m}$ extended from the left bow of the ship edge.

During the second cruise (OR1-802) in 2006, the Eddy Covariance System (ECS) was installed onboard. It was mounted at $12 \mathrm{~m}$ above the sea surface. The ECS consisted of 2 fast-response instruments: a 3-D ultrasonic anemometer (81000, Young, USA) and an open path infrared hygrometer/ $\mathrm{CO}_{2}$ sensor (7500, LICOR, USA). The anemometer measures three orthogonal wind components $(u, v, w)$ and virtual air temperature at $10 \mathrm{~Hz}$. The open path infrared hygrometer sensor measures the concentrations of water vapor also at $10 \mathrm{~Hz}$. In addition, a Gyro enhanced orientation sensor (3DM-G, MicroStrain, USA) was installed $2 \mathrm{~m}$ below the 3-D anemometer to measure the ship rotation angles (roll, pitch, yaw) at $10 \mathrm{~Hz}$. Using GPS and Gyro data, the measured wind vector was corrected for ship movement according to Edson et al. (1998). ECS has been applied over the sea for measuring turbulent fluxes by Kowalski (2001), McGillis et al. (2001) and Blomquist et al. (2006). Using the
ECS, friction velocity $\left(u^{*}\right)$, sensible heat flux $(H)$ and latent heat flux $(L E)$ can be determined as:

$$
\begin{aligned}
& u^{*}=\left(\overline{w^{\prime} u^{2}}+\overline{w^{\prime} v^{2}}\right)^{0.25} \\
& H=\rho_{a} c_{a} \overline{w^{\prime} \theta^{\prime}} \\
& L E=\rho_{a} L_{v} \overline{w^{\prime} q^{\prime}}
\end{aligned}
$$

where $u^{\prime}, v^{\prime}$, and $w^{\prime}$ are the fluctuations of E-W, S-N, and vertical wind components $\left(\mathrm{m} \mathrm{s}^{-1}\right)$, respectively. $\rho_{a}$ is the density of air $\left(\mathrm{kg} \mathrm{m}^{-3}\right)$ and $c_{a}$ the specific heat capacity at constant pressure $\left(\mathrm{J} \mathrm{kg}^{-1} \mathrm{~K}^{-1}\right) . L_{v}$ is the latent heat of evaporation of water. $\theta^{\prime}$ and $q^{\prime}$ denote fluctuations in potential temperature $(\mathrm{K})$ and specific humidity $\left(\mathrm{kg} \mathrm{kg}^{-1}\right)$, respectively. In addition, under the assumption of the mean vertical velocity being zero, two-axis coordinate rotation is applied to all ECS estimates according to Wilczak et al. (2001).

\section{ONE-COLUMN OCEAN MODEL}

A one-column ocean model ( $\mathrm{Tu}$ and Tsuang 2005) was used to simulate the SSST and surface energy components. The model was previously tested at a TOGA site. The sea water temperature $(T)$, current $(\vec{u})$, and salinity $(S)$ are determined (Martin 1985; Gaspar et al. 1990) as:

$$
\begin{aligned}
& \frac{\partial T}{\partial t}=\left(k_{h}+v_{h}\right) \frac{\partial^{2} T}{\partial z^{2}}+\frac{R_{s n}}{\rho_{w 0} c_{w}} \frac{\partial F}{\partial z} \\
& \frac{\partial \vec{u}}{\partial t}=-f \hat{k} \times \vec{u}+\left(k_{m}+v_{m}\right) \frac{\partial^{2} \vec{u}}{\partial z^{2}} \\
& \frac{\partial S}{\partial t}=\left(k_{h}+v_{h}\right) \frac{\partial^{2} S}{\partial z^{2}}
\end{aligned}
$$

where $R_{s n}$ is net solar radiation at the surface $\left(\mathrm{W} \mathrm{m}^{-2}\right) ; F(z)$ is the fraction (dimensionless) of $R_{s n}$ that penetrates to the depth $z ; k_{h}$ and $k_{m}$ are eddy diffusion coefficients for heat and momentum $\left(\mathrm{m}^{2} \mathrm{~s}^{-1}\right)$, respectively. The value of $k_{h}$ within the cool skin and that of $k_{m}$ within the viscous layer are set to zero. That is, molecular transport is the only mechanism for the vertical diffusion of heat and momentum in the cool skin and in the viscous layer, respectively (Hasse 1971; Grassl 1976; Wu 1985). The molecular diffusion coefficient for momentum $v_{m}$ is set at $1.20 \times 10^{-6} \mathrm{~m}^{2} \mathrm{~s}^{-1}$, and that for heat $v_{h}$ is set at $1.34 \times 10^{-7} \mathrm{~m}^{2} \mathrm{~s}^{-1}$ (Mellor and Durbin 1975; Paulson and Simpson 1981; Chia and Wu 1998). $\rho_{w 0}$ is the density $\left(\mathrm{kg} \mathrm{m}^{-3}\right)$ of the water and $c_{w}$ the specific heat capacity at constant pressure $\left(\mathrm{J} \mathrm{kg}^{-1} \mathrm{~K}^{-1}\right) . S$ is salinity (\%o), $\vec{u}$ is current velocity $\left(\mathrm{m} \mathrm{s}^{-1}\right), f$ is the Coriolis parameter (dimensionless), and $\hat{k}$ is the vertical unit vector $\left(\mathrm{m} \mathrm{s}^{-1}\right)$. 

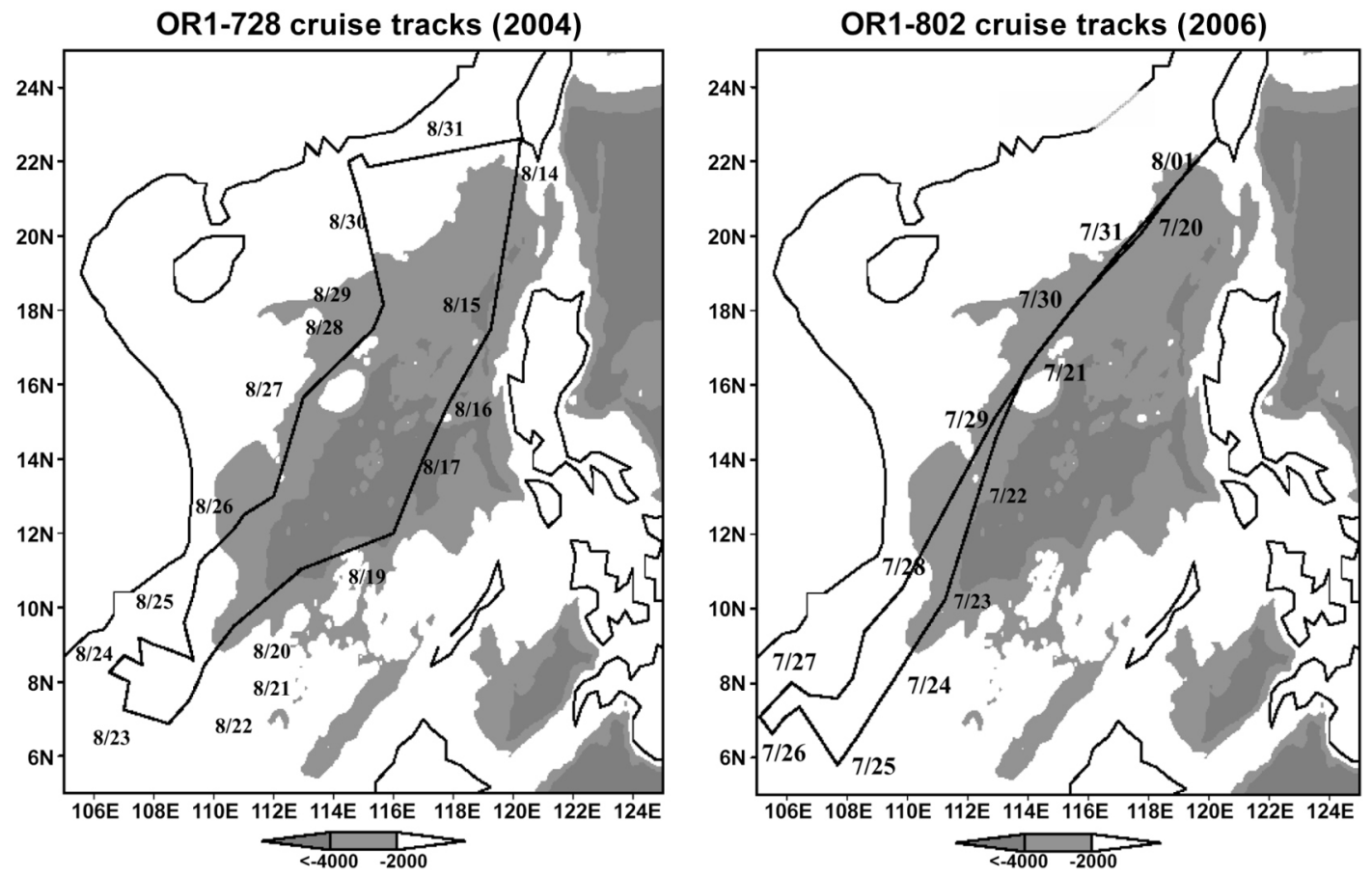

Fig. 1. Bathymetry (shaded plot in m) and cruise tracks of OR1-728 in 2004 and OR1-802 in 2006.

The eddy diffusivity for momentum $k_{m}$ is simulated by an eddy kinetic energy approach based on the PrandtlKolmogorov hypothesis as:

$k_{m}=c_{k} l_{k} \sqrt{E}$

where $c_{k}=0.1$ (Gaspar et al. 1990), $l_{k}$ is a mixing length (m), and $E$ is turbulent kinetic energy, $E=0.5\left(u^{\prime 2}+v^{\prime 2}+w^{\prime 2}\right)$. The turbulent kinetic energy $(E)$ is determined by a onedimensional equation (Mellor and Yamada 1982) as:

$\frac{\partial E}{\partial t}=\frac{\partial}{\partial z} k_{m} \frac{\partial E}{\partial z}+k_{m}\left(\frac{\partial \vec{u}}{\partial z}\right)^{2}+k_{h} \frac{g}{\rho_{w}} \frac{\partial \rho_{w}}{\partial z}-c_{\varepsilon} \frac{E^{3 / 2}}{l_{\varepsilon}}$

where $c_{\varepsilon}=0.7$ (Bougeault and Lacarrere 1989; Gaspar et al. 1990); $g$ is gravity $\left(\mathrm{m} \mathrm{s}^{-2}\right) ; \rho_{w}$ is the density of water $\left(\mathrm{kg} \mathrm{m}^{-3}\right)$; and $l_{\varepsilon}$ is a characteristic dissipation length $(\mathrm{m})$. Mixing length $\left(l_{k}\right)$ and dissipation length $\left(l_{\varepsilon}\right)$ are determined according to Gaspar et al. (1990). This approach is valid for determining eddy diffusivity of both the ocean mixed layer and the surface layer. The relationship between $k_{m}$ and $k_{h}$ is determined according to the Prandtl number (Mellor and Yamada 1982; Martin 1985; Gaspar et al. 1990; Pinazo et al. 1996; Leredde et al. 1999) as:

$P_{r t}=\frac{k_{m}}{k_{h}}$
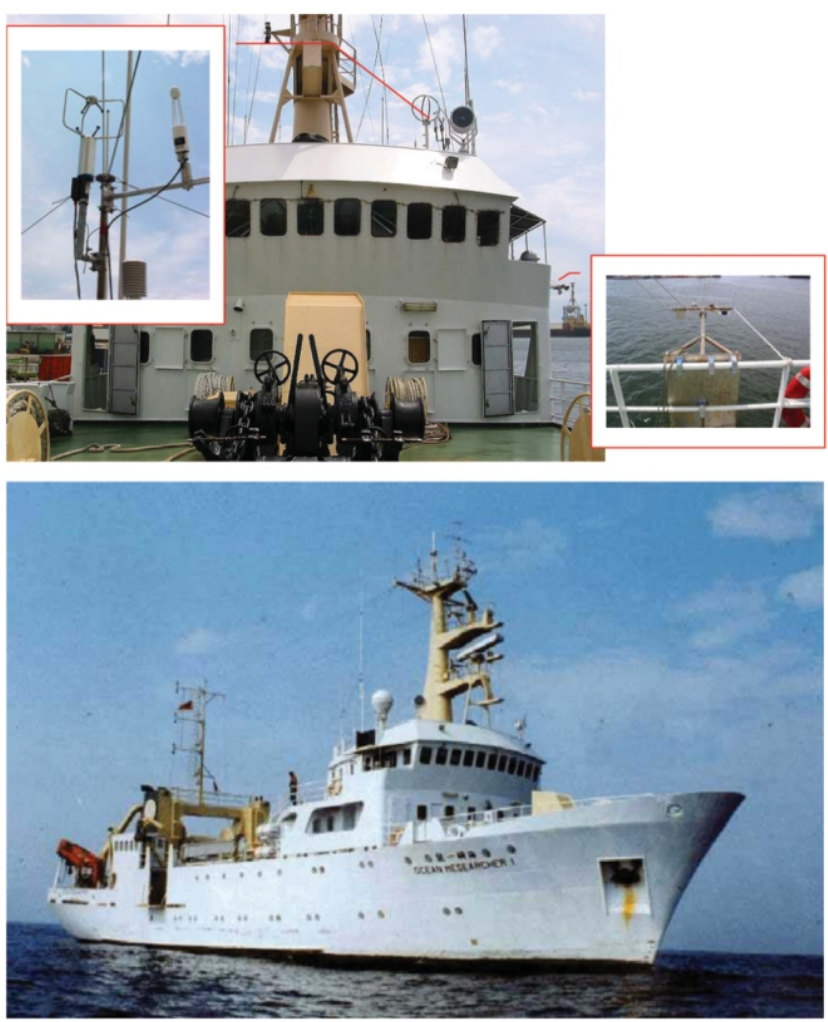

Fig. 2. Appearance of R/V OR1 and it's equipped instruments, includes Eddy Covariance System (ECS), 3-D ultrasonic anemometer (81000, Young, USA) and an open path infrared hygrometer $/ \mathrm{CO}_{2}$ sensor $(7500$, LICOR, USA), Eppley Pyranometer (PSP, EPLAB, USA) and an Eppley Pyrgeometer (PIR, EPLAB, USA). 
where $P_{r t}$ is turbulent Prandtl number (dimensionless). An unity value for $P_{r t}$ is used in this study. The unity value is used in many recent numerical models (Gaspar et al. 1990; Pinazo et al. 1996; Leredde et al. 1999) and has been observed in ocean data (Gregg et al. 1985; Peters et al. 1988), although Mellor and Yamada (1982) and Martin (1985) used a value of 0.8 . The thickness of the ocean cool skin is determined according to Artale et al. (2002), which is a method valid for wind speed lower and higher than $8 \mathrm{~m} \mathrm{~s}^{-1}$ (Tu and Tsuang 2005). In addition, the surface effective thickness for oceans (Tsuang et al. 2008b) is used to discretize the heat diffusion equation for the uppermost numerical layer.

The friction velocity, Monin-Obukhov length, surface latent and sensible heat fluxes were determined according to the similarity theory (Businger et al. 1971) with the modified stability function of Brutsaert $(1982,1992)$. Surface roughness $\left(z_{0}\right)$ was determined according to Kraus and Businger (1994) as:

$z_{0}=\frac{0.11 \times v_{m}}{u^{*}}+0.1 \times \sqrt{\frac{v_{m} \times u^{*}}{g}}+\frac{0.015 \times u^{* 2}}{g}(10)$

In the model, 9-band absorption coefficients of solar radiation are set according to Soloviev and Schlussel (1996), with the first band to be the same as in Fairall et al. (1996).

At the surface, net non-solar surface heat flux $Q_{n s}\left(\mathrm{~W} \mathrm{~m}^{-2}\right)$ (positive downward), is given by:

$Q_{n s}=R_{l d}-R_{l u}-H-L E$

It is the sum of atmospheric longwave radiation $\left(R_{l d}\right)$, terrestrial longwave radiation $\left(R_{l u}\right)$, sensible heat flux $(H)$, and latent heat flux $(L E)$ at the sea surface. The terrestrial longwave radiation can be determined according to the Stefan-Boltzman law as:

$R_{l u}=\varepsilon \sigma T_{s}^{4}$

where $\varepsilon$ is the emissivity of ocean as 0.96 (dimensionless), and $\sigma$ is the Stefan-Boltzman constant as $5.67 \times$ $10^{-8} \mathrm{~W} \mathrm{~m}^{-2} \mathrm{k}^{-4}$.

The model determines the vertical profiles of temperature and momentum of a water column from the surface down to $15 \mathrm{~m}$ depth. In the model, water temperatures at depths equal to or deeper than $15 \mathrm{~m}$ are updated according to the observations. Setting such a boundary condition reduces the error of SSST simulation, since horizontal advection heat flux is not included in the one-column ocean model. Salinity is set at $34.26 \%$, observed by the CTD. A very fine 36-layer vertical discretization is set, used in the upper $15 \mathrm{~m}$ of the ocean. The 36 layers are at the surface, and at depths of $50,150,250,350,450,550,650,750,850,950 \mu \mathrm{m}, 1.5,2.5$,
$4,7.5 \mathrm{~mm}, 1.5,2.5,4,7.5,15,25,35,45,55,65,75,85,95$ $\mathrm{cm}, 1.5,2.5,3.5,4.5,5.5,6.5,7.5,8.5$, and $9.5 \mathrm{~m}$. A $900 \mathrm{~s}$ model time step (as in Gaspar et al. 1990) is used.

The model inputs are wind speed, humidity, surface air temperature, atmospheric pressure, net solar radiation, atmospheric radiation and lower boundary water temperature. The outputs of the model include surface turbulent heat fluxes, friction velocity, stability, aerodynamic resistance, water temperature, water salinity and current velocity. The observed meteorological data (wind speed, humidity, surface air temperature, atmospheric pressure, incoming solar radiation, and atmospheric radiation) were used to drive the one-column ocean model. Missing values were filled by the NCEP2 data or the same local time data in the previous days. For evaluation of the model, terrestrial longwave radiation, sensible heat flux, and latent heat flux are computed from the model SSST and compared against the direct measurements.

\section{RESULTS AND DISCUSSION}

Here the measurements are presented and compared with those of the NCEP 2 reanalysis and those simulated by the one-column ocean model.

\subsection{Observed Meteorological Factors and Surface Energy Components}

The SCS is largely confined within the Tropic of Cancer; therefore, it experiences a monsoonal climate due to the effects from the summer southwest monsoon (Morton and Blackmore 2001; Jilan 2004). The meteorological conditions observed during the two cruises are listed in Table 1 and shown in Figs. 3 and 4. On sunny days, on OR1-728, the incoming solar radiation reached $850 \mathrm{~W} \mathrm{~m}^{-2}$ and on OR1802 , it reached $1000 \mathrm{~W} \mathrm{~m}^{-2}$. There were several overcast periods during the cruises (18 and 28 August 2004, 21 and 29 July 2006). During these overcast periods, the magnitude of solar radiation was much lower than in other periods where cloud cover approached $100 \%$ according to NCEP2. During clear sky conditions, the incoming solar radiation was about $990 \mathrm{~W} \mathrm{~m}^{-2}$ at noon on 19, 20, 31 July, and $1 \mathrm{Au}-$ gust 2006. This value is close to the values on clear-sky days (2 and 22 May, 29 June 1998) observed at Dungsha Island $\left(20^{\circ} 42^{\prime} \mathrm{N}, 116^{\circ} 43^{\prime} \mathrm{E}\right)$ (Lin et al. 2002) during the SCS monsoon experiment (May - June 1998). Lester and Myers (2006) indicate accurate global solar radiation measurements are crucial to climate change research and development of solar energy technologies. Solar radiation is also important data for our model for estimating SSST.

The representative albedo during the two cruises was 0.07 - 0.08 during daylight hours (10 am - $4 \mathrm{pm})$. The observed diurnal pattern of albedo was U-shaped with the minimum at 0.04 at noon, and the maximum at 0.3 at sunrise and 
sunset. Payne (1972) uses a fixed platform data to express albedo in terms of a particularly convenient pair of parameters and indicates the subtropics mean albedo is 0.06 in the summer for the Atlantic Ocean.

During both cruises, the near-surface air temperature was between 298 and $305 \mathrm{~K}$. The highest temperature occurred along the coast, in the northern part of the SCS on OR1-728 and in the Vietnam neritic zone on OR1-802. The lowest temperature occurred in the central part of the SCS, where it is deepest. On OR1-728 the average air temperature was $301 \pm 0.2 \mathrm{~K}$, the atmospheric pressure was $1007 \pm 3 \mathrm{hPa}$, and the sea surface specific humidity $(q)$ was $20 \pm 1 \mathrm{~g} \mathrm{~kg}^{-1}$. The observed specific humidity is close to the value at 18 $20 \mathrm{~g} \mathrm{~kg}^{-1}$, compiled in the Comprehensive Ocean-Atmosphere Data Set (COADS), over the SCS in 1988 - 1993 (Jones et al. 1999). The average wind speeds of the two cruises were $9 \pm 3$ and $9 \pm 5 \mathrm{~m} \mathrm{~s}^{-1}$ with prevailing winds from the southwest during both cruises. This is consistent with Morton and Blackmore (2001).

The SSST was calculated from observed $R_{l u}$ according to Eq. (12) with the emissivity at 0.96 (Fig. 5). Using the emissivity at 0.96 , the derived SSST was slightly lower the water temperature at $4-\mathrm{m}$ depth by about $0.2 \mathrm{~K}$ most of the time. The difference is due to the cool skin mechanism, well recognized in the literature (e.g., Donlon et al. 2002). Subrahamanyam and Ramachandran (2002) set the emissivity at 0.95 during the Indian Ocean Experiment on the research vessel, Ocean Research 1 (R/V OR1). In global emissivity datasets, the emissivity over SCS is set at $0.92-0.93$ in Zhang et al. (2004) and 0.99 in Wilber et al. (1999), based on emissivity inventory. In addition, Fig. 5 also shows the observed water temperatures at 4-, 10-, and 15-m depths at stops. The figure shows that the water temperature was the highest in the north $\operatorname{SCS}\left(15-20^{\circ} \mathrm{N}\right)$, the second highest in

Table 1. Summary of meteorological factors and surface energy components observed during the cruises from 15 August to 2 September 2004 (OR1-728) and from 19 July to 2 August 2006 (OR1-802), where the parentheses denote the valid numbers of hourly data.

\begin{tabular}{|c|c|c|c|c|c|c|}
\hline \multirow{2}{*}{ Variables } & \multicolumn{3}{|c|}{15 August to 2 September 2004} & \multicolumn{3}{|c|}{19 July to 2 August 2006} \\
\hline & daytime & nighttime & all & daytime & nighttime & all \\
\hline 1. Air temperature $(\mathrm{K})$ & $\begin{array}{l}301.3 \pm 0.2 \\
\quad(247)\end{array}$ & $\begin{array}{l}301.2 \pm 0.1 \\
\quad(176)\end{array}$ & $\begin{array}{c}301.2 \pm 0.2 \\
(423)\end{array}$ & $\begin{array}{l}301.9 \pm 0.9 \\
\quad(175)\end{array}$ & $\begin{array}{l}301.8 \pm 0.6 \\
\quad(135)\end{array}$ & $\begin{array}{l}301.9 \pm 0.8 \\
(310)\end{array}$ \\
\hline $\begin{array}{l}\text { 2. Atmospheric pressure } \\
(\mathrm{hPa})\end{array}$ & $\begin{array}{c}1006.8 \pm 2.9 \\
(250)\end{array}$ & $\begin{array}{c}1006.8 \pm 2.9 \\
(177)\end{array}$ & $\begin{array}{c}1006.6 \pm 2.8 \\
(427)\end{array}$ & $\begin{array}{l}1008.0 \pm 2.0 \\
(182)\end{array}$ & $\begin{array}{c}1008.4 \pm 2.0 \\
(153)\end{array}$ & $\begin{array}{c}1008.2 \pm 2.0 \\
(335)\end{array}$ \\
\hline $\begin{array}{l}\text { 3. Specific humidity } \\
\qquad\left(\mathrm{g} \mathrm{kg}^{-1}\right)\end{array}$ & $\begin{array}{l}19.7 \pm 1.0 \\
(106)\end{array}$ & $\begin{array}{l}19.4 \pm 0.6 \\
(74)\end{array}$ & $\begin{array}{l}19.6 \pm 0.6 \\
(180)\end{array}$ & $\begin{array}{l}19.9 \pm 5.9 \\
(127)\end{array}$ & $\begin{array}{l}20.8 \pm 6.9 \\
\quad(110)\end{array}$ & $\begin{array}{l}20.9 \pm 6.4 \\
\quad(237)\end{array}$ \\
\hline 4. Wind speed $\left(\mathrm{m} \mathrm{s}^{-1}\right)$ & $\begin{array}{l}9.2 \pm 3.2 \\
(250)\end{array}$ & $\begin{array}{l}9.4 \pm 3.1 \\
(177)\end{array}$ & $\begin{array}{l}9.3 \pm 3.1 \\
(427)\end{array}$ & $\begin{array}{c}8.7 \pm 4.6 \\
(182)\end{array}$ & $\begin{array}{l}9.3 \pm 5.0 \\
(153)\end{array}$ & $\begin{array}{l}9.0 \pm 4.8 \\
(335)\end{array}$ \\
\hline $\begin{array}{l}\text { 5. Incoming solar radiation } \\
\left(\mathrm{W} \mathrm{m}^{-2}\right)\end{array}$ & $\begin{array}{c}362 \pm 285 \\
\quad(427)\end{array}$ & $\begin{array}{c}0 \\
(177)\end{array}$ & $\begin{array}{l}212 \pm 281 \\
(427)\end{array}$ & $\begin{array}{l}351 \pm 328 \\
\quad(188)\end{array}$ & $\begin{array}{c}0 \\
(147)\end{array}$ & $\begin{array}{c}197 \pm 301 \\
(335)\end{array}$ \\
\hline $\begin{array}{l}\text { 6. Atmospheric longwave } \\
\text { radiation }\left(\mathrm{W} \mathrm{m}^{-2}\right)\end{array}$ & $\begin{array}{l}405 \pm 10 \\
(178)\end{array}$ & $\begin{array}{c}397 \pm 10 \\
(132)\end{array}$ & $\begin{array}{l}402 \pm 11 \\
(310)\end{array}$ & $\begin{array}{c}403 \pm 10 \\
(116)\end{array}$ & $\begin{array}{l}396 \pm 10 \\
(99)\end{array}$ & $\begin{array}{c}400 \pm 11 \\
(215)\end{array}$ \\
\hline $\begin{array}{l}\text { 7. Terrestrial longwave } \\
\text { radiation }\left(\mathrm{W} \mathrm{m}^{-2}\right)\end{array}$ & $\begin{array}{l}450 \pm 6 \\
(198)\end{array}$ & $\begin{array}{l}451 \pm 5 \\
(147)\end{array}$ & $\begin{array}{c}450 \pm 6 \\
(345)\end{array}$ & $\begin{array}{l}457 \pm 5 \\
(182)\end{array}$ & $\begin{array}{l}455 \pm 5 \\
(150)\end{array}$ & $\begin{array}{c}456 \pm 5 \\
(335)\end{array}$ \\
\hline 8. SSST (K) & $\begin{array}{l}301.5 \pm 1.0 \\
\quad(197)\end{array}$ & $\begin{array}{l}301.7 \pm 0.9 \\
\quad(147)\end{array}$ & $\begin{array}{c}301.6 \pm 0.9 \\
(344)\end{array}$ & $\begin{array}{l}302.4 \pm 0.9 \\
\quad(182)\end{array}$ & $\begin{array}{l}302.2 \pm 0.8 \\
\quad(150)\end{array}$ & $\begin{array}{c}302.3 \pm 0.8 \\
(332)\end{array}$ \\
\hline 9. Friction velocity $\left(\mathrm{m} \mathrm{s}^{-1}\right)$ & & & & $\begin{array}{l}0.5 \pm 0.2 \\
\quad(63)\end{array}$ & $\begin{array}{l}0.4 \pm 0.2 \\
\quad(44)\end{array}$ & $\begin{array}{l}0.4 \pm 0.2 \\
(107)\end{array}$ \\
\hline $\begin{array}{l}\text { 10. Surface sensible heat } \\
\text { flux }\left(\mathrm{W} \mathrm{m}^{-2}\right)\end{array}$ & & & & $\begin{array}{c}12 \pm 25 \\
(84)\end{array}$ & $\begin{array}{c}8 \pm 16 \\
(62)\end{array}$ & $\begin{array}{c}10 \pm 22 \\
(146)\end{array}$ \\
\hline $\begin{array}{l}\text { 11. Surface latent heat flux } \\
\left(\mathrm{W} \mathrm{m}^{-2}\right)\end{array}$ & & & & $\begin{array}{c}181 \pm 172 \\
(37)\end{array}$ & $\begin{array}{l}125 \pm 120 \\
(22)\end{array}$ & $\begin{array}{c}160 \pm 156 \\
(59)\end{array}$ \\
\hline
\end{tabular}



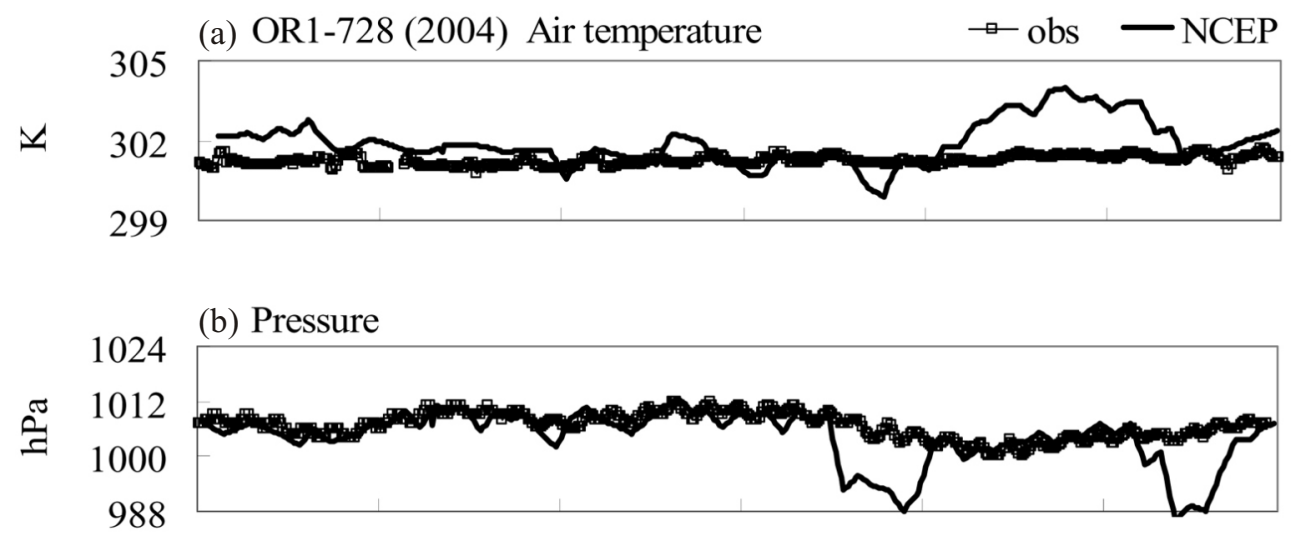

(c) Windspeed

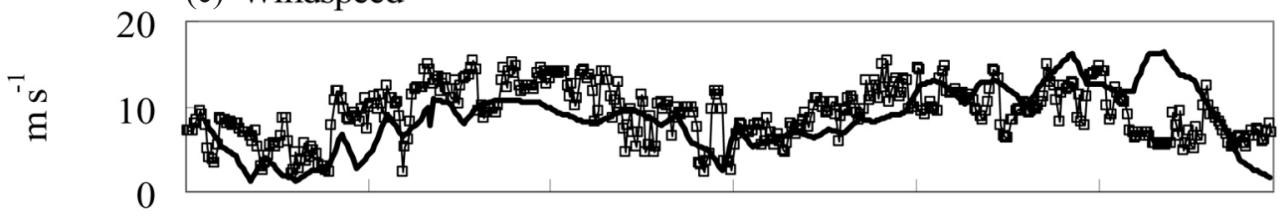

(d) Incoming solar radiation $\quad$ NCEP

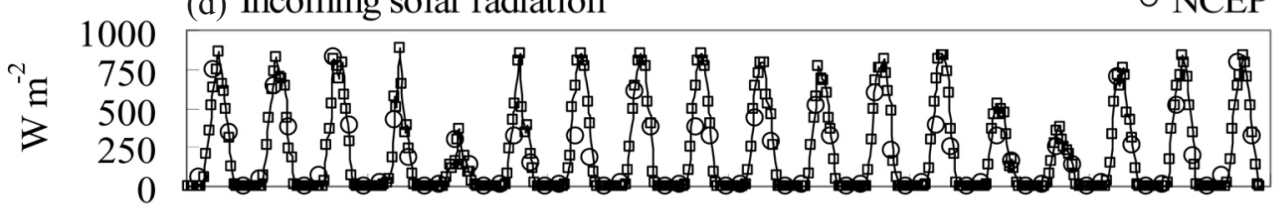

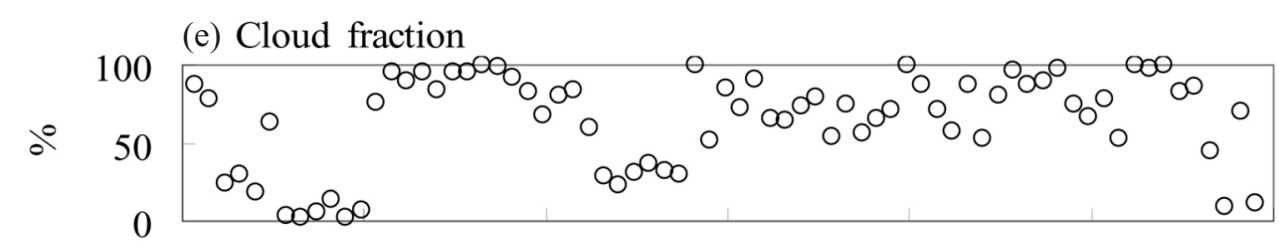

(f) Specific humidity

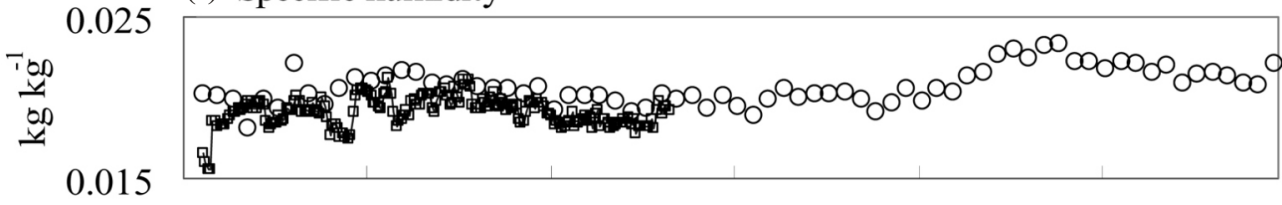

(g) Atmospheric longwave radiation

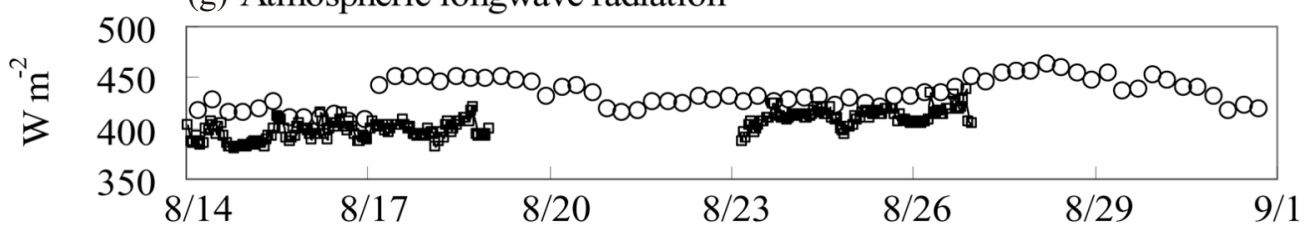

Fig. 3. Comparison of meteorological variables observed during the OR1-728 cruise in 2004 with those from the NCEP2 reanalysis, where "obs" is thin line containing square $(\because)$ denotes the observations made especially for the campaign during the cruise, and the thick line $(-)$ or circle $(\bigcirc)$ is NCEP2 reanalysis. 


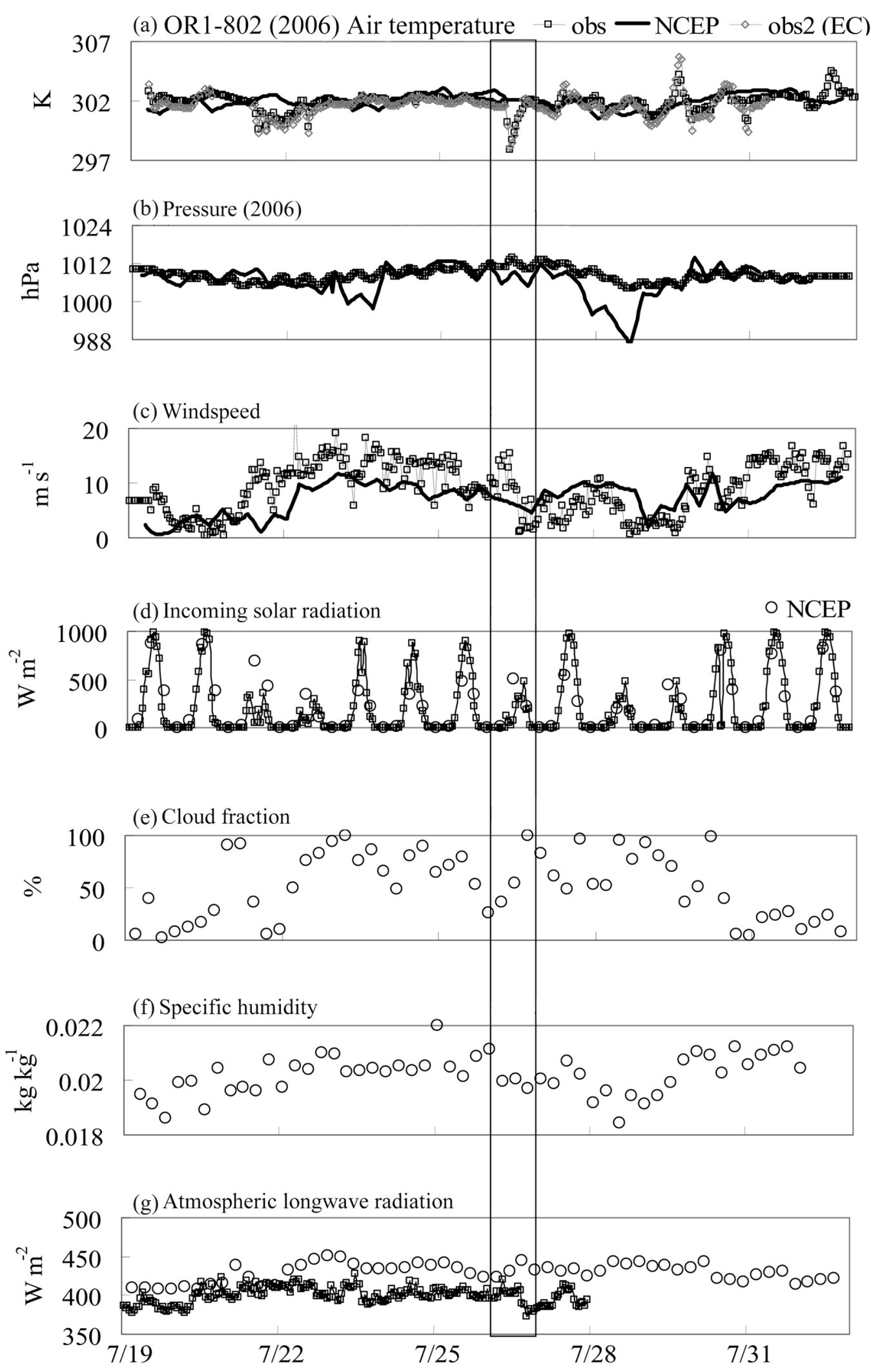

Fig. 4. Same as Fig. 3 but for the OR1-802 cruise in 2006. The thin line containing square ( $\square)$ is observed data; the thick line (一) or circle (O) is NCEP2 reanalysis, and the thin line containing diamond $(\forall)$ is ECS observed data. 

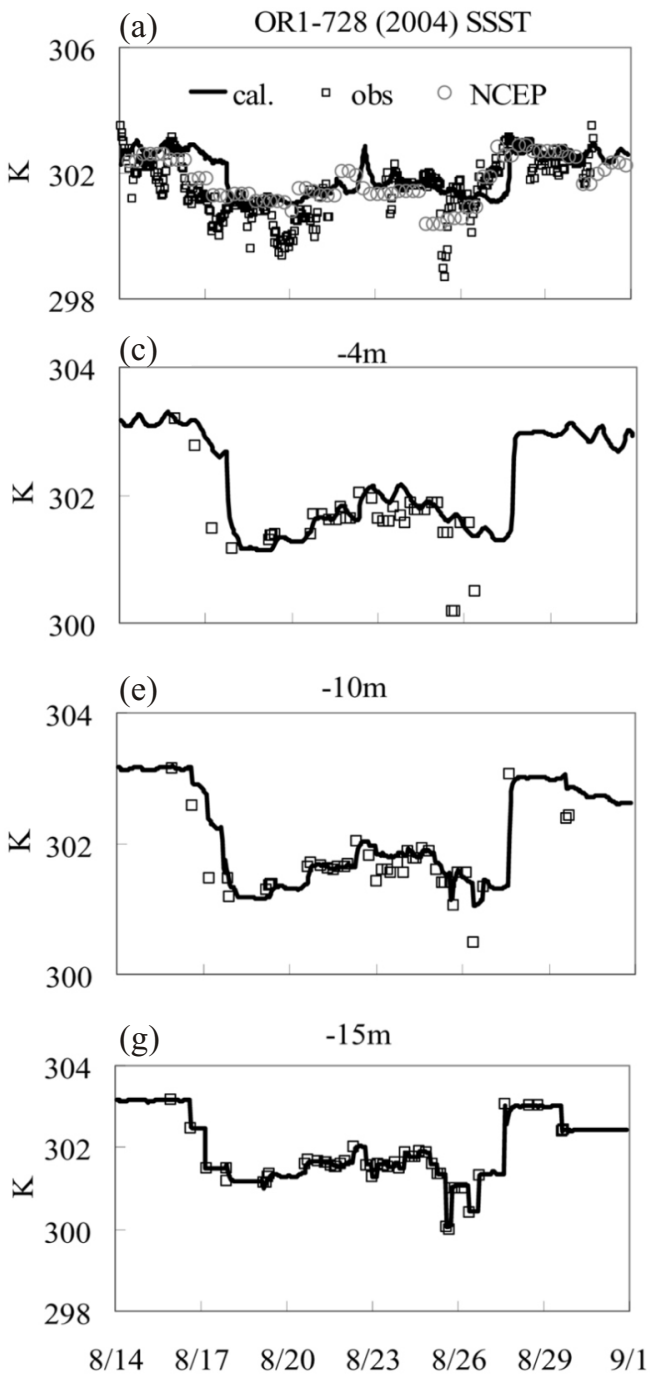
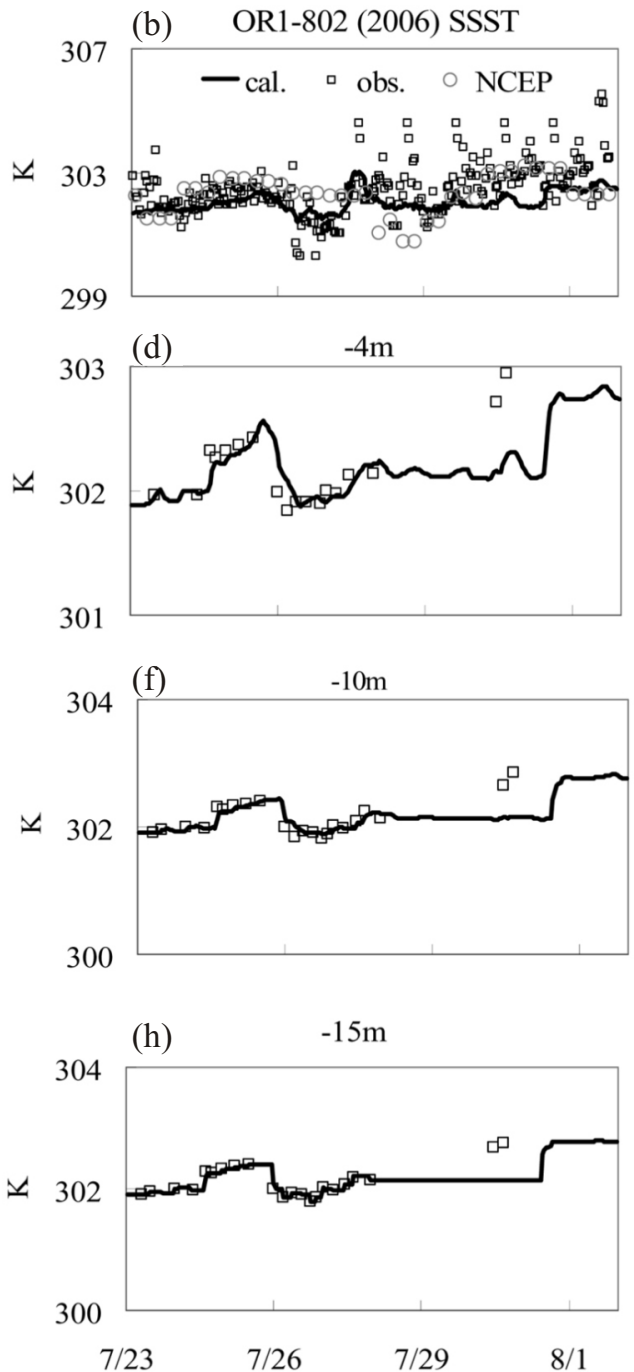

Fig. 5. Comparison of simulated water temperatures at 4, 10, and $15 \mathrm{~m}$ depths with observations during OR1-728 (2004) and OR1-802 (2006) cruises. Note that the observed temperature at $15-\mathrm{m}$ depth is set as the lower boundary conditions for the simulation. The square ( $\square$ ) is observed data; the thick line $(-)$ is model simulation and circle $(O)$ is NCEP2 reanalysis.

the south SCS $\left(6-10^{\circ} \mathrm{N}\right)$ and the lowest in the central SCS $\left(10-15^{\circ} \mathrm{N}\right)$. Note that in the central SCS, the depth is much deeper than in the north and south SCS. This is consistent with the World Ocean Atlas 2005 dataset (Locarnini et al. 2006). Uu and Brankart (1997) observed the water temperature at 10-m depth by with CTD in the summer over the SCS in the range from $301-302 \mathrm{~K}$, which is also in the same range to this study.

With respect to the surface energy components (solar radiation, atmospheric longwave radiation, terrestrial longwave radiation, latent heat flux, and sensible heat flux), the observations show that solar radiation is stronger than latent heat flux, and latent heat flux is stronger than sensible heat flux (Figs. 3, 4, 6, 7, and Table 1). During the day, solar radiation is stronger than terrestrial radiation, and the terrestrial radiation is stronger than atmospheric radiation. At night, when there is no solar radiation, terrestrial radiation is stronger than atmospheric radiation.

The mean friction velocity during the second cruise was observed to be $0.4 \pm 0.2 \mathrm{~m} \mathrm{~s}^{-1}$, the mean latent heat flux 160 $\pm 156 \mathrm{~W} \mathrm{~m}^{-2}$, and the mean sensible heat flux $10 \pm 22 \mathrm{~W} \mathrm{~m}^{-2}$ (Table 1). McGillis et al. (2004) measured meteorological conditions directly, latent heat flux and sensible heat flux, on the NOAA ship Ronald H. Brown during GasEx-2001 in the eastern equatorial Pacific Ocean, their observed wind speed was relatively low at $6.1 \pm 1.3 \mathrm{~m} \mathrm{~s}^{-1}$ with friction velocity, latent heat flux and sensible heat flux at $0.2 \pm 0.17 \mathrm{~m} \mathrm{~s}^{-1}$, $83.2 \pm 51.3$, and $4.4 \pm 7.1 \mathrm{~W} \mathrm{~m}^{-2}$, respectively. The average wind speed of this study was 1.5 times than that of McGillis et al. (2004), and the friction velocity, latent heat flux and sensible heat flux were $1.5-2.0$ times than those of their studies. Subrahamanyam and Ramachandran (2002) showed 
(a) OR1-728 (2004) a obs. — cal. ○ NCEP

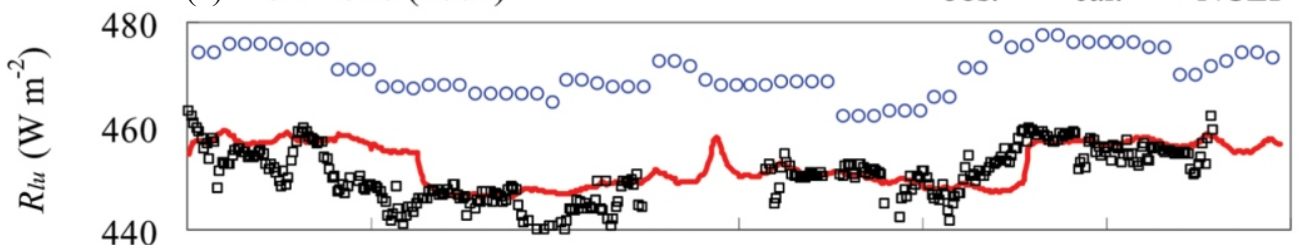

440

(b)

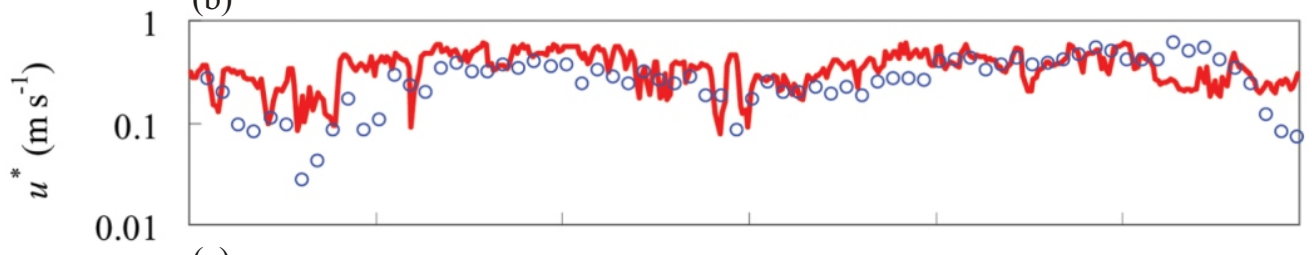

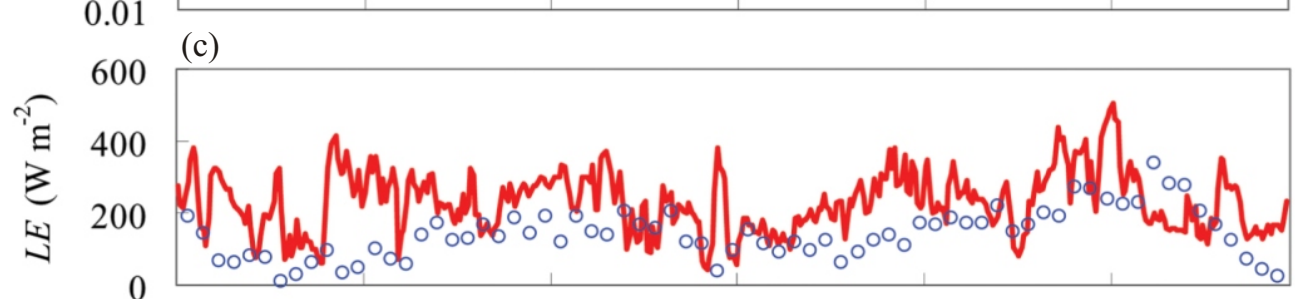

(d)

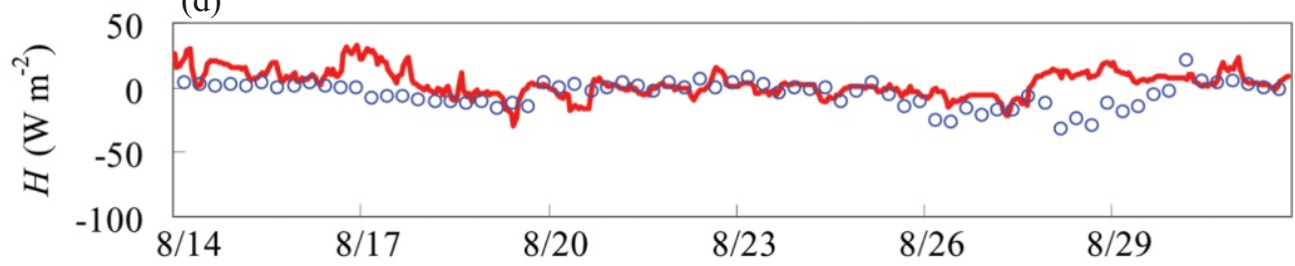
(e) OR1-802 (2006)
- obs. - cal. ○ NCEP
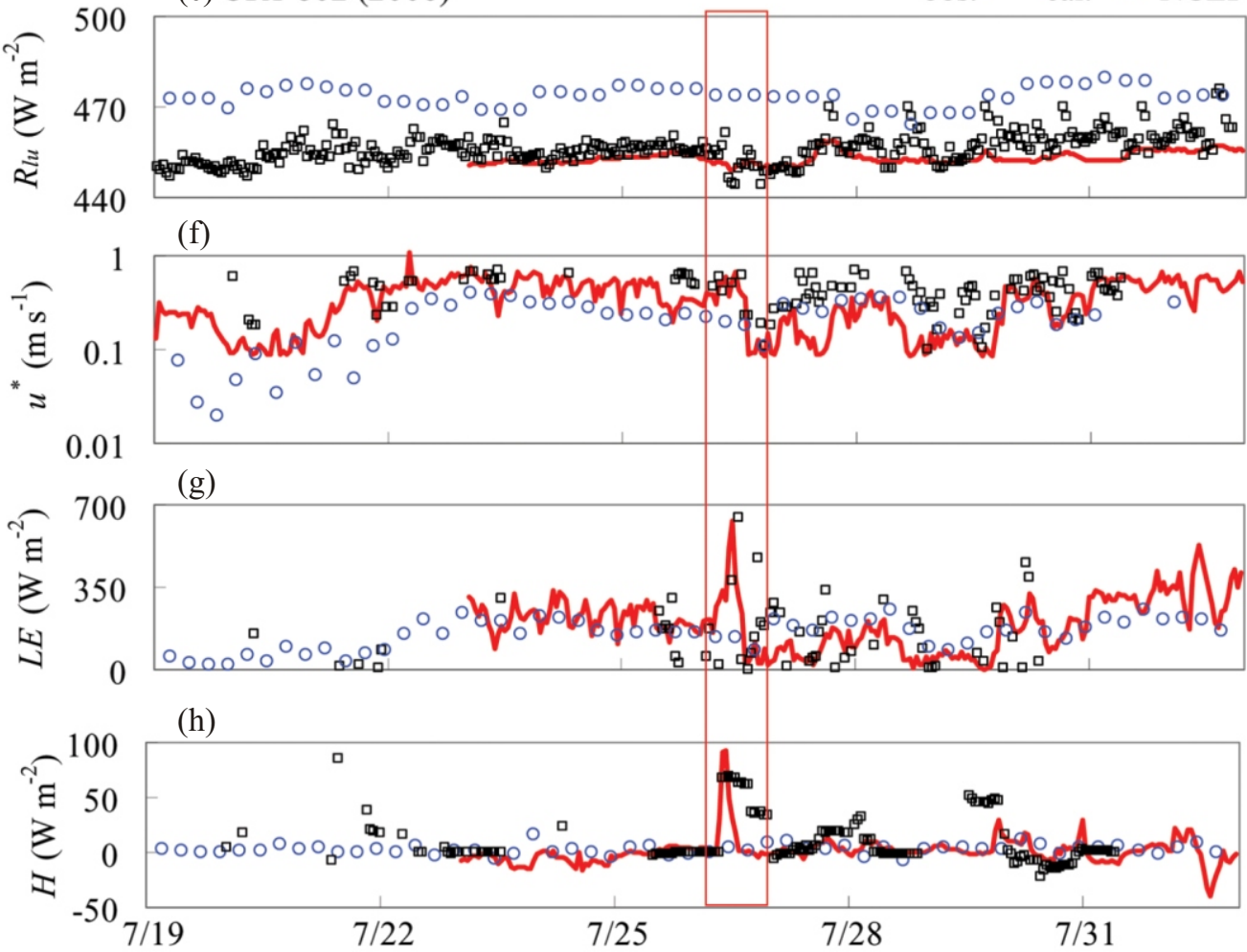

Fig. 6. Comparisons of calculated terrestrial longwave radiation $\left(R_{l u}\right)$, friction velocity $\left(u^{*}\right)$, surface latent heat flux $(L E)$, and surface sensible heat flux $(H)$ with observation (obs.), model estimation (cal.), and NCEP2 data during OR1-728 (2004) and OR1-802 (2006) cruises. The square ( $\square$ ) is observed data; the red thick line $(-)$ is model simulation and circle $(O)$ is NCEP2 reanalysis. 


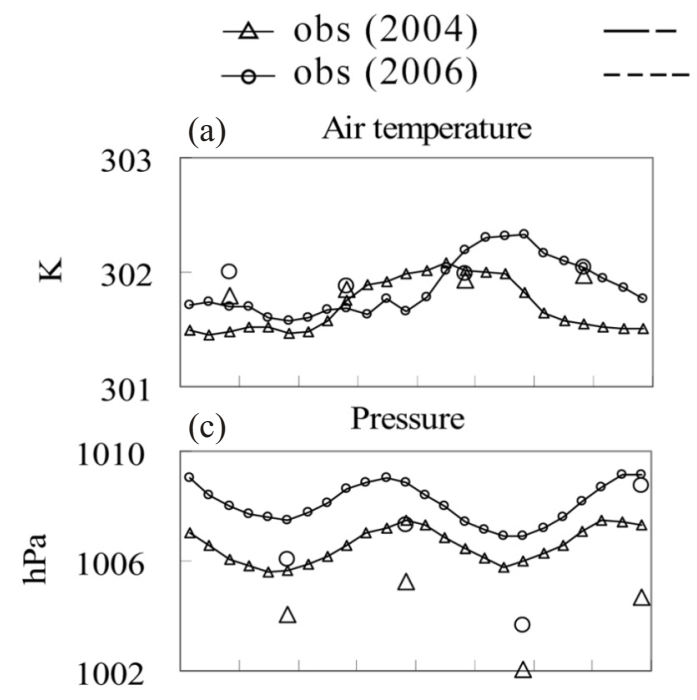

cal. (2004)

$\triangle$ NCEP (2004)

cal. (2006)

O NCEP (2006)

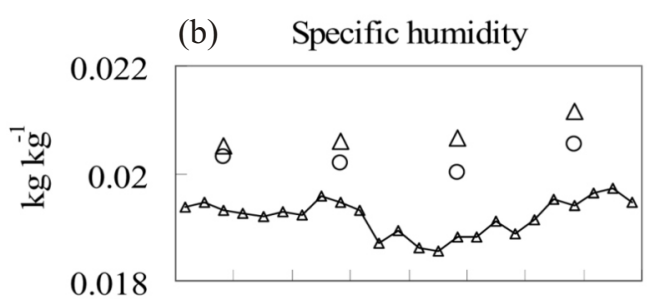

0.018
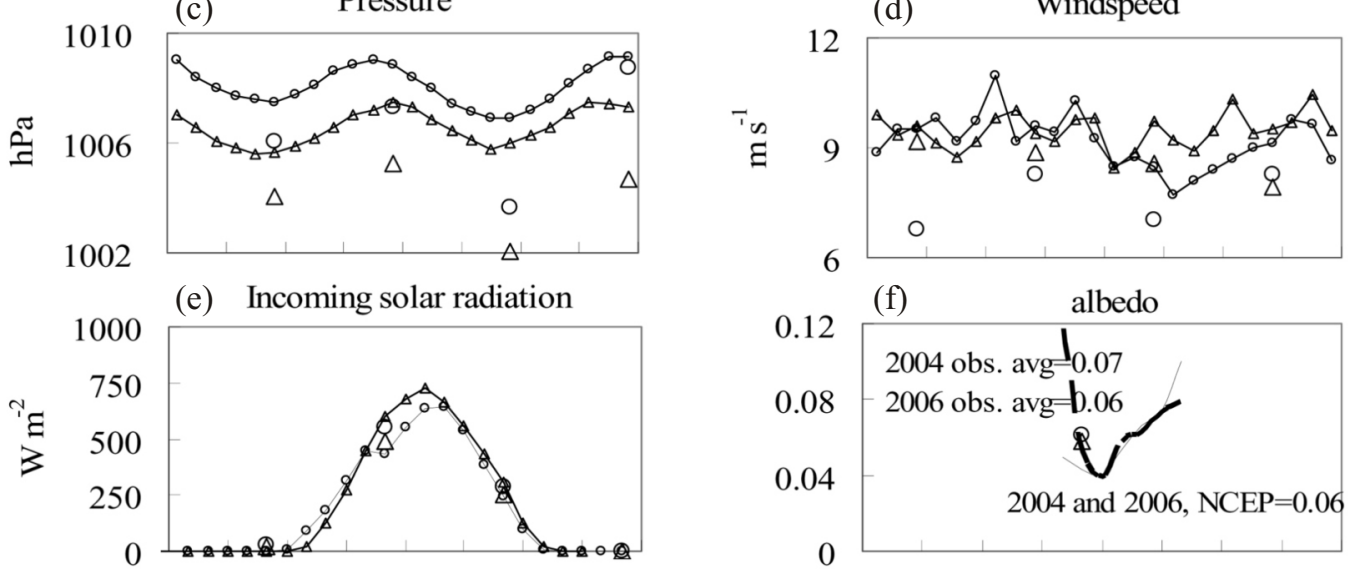

(g)

LE

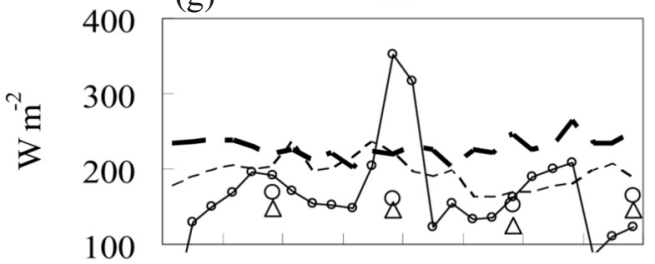

(h) SSST
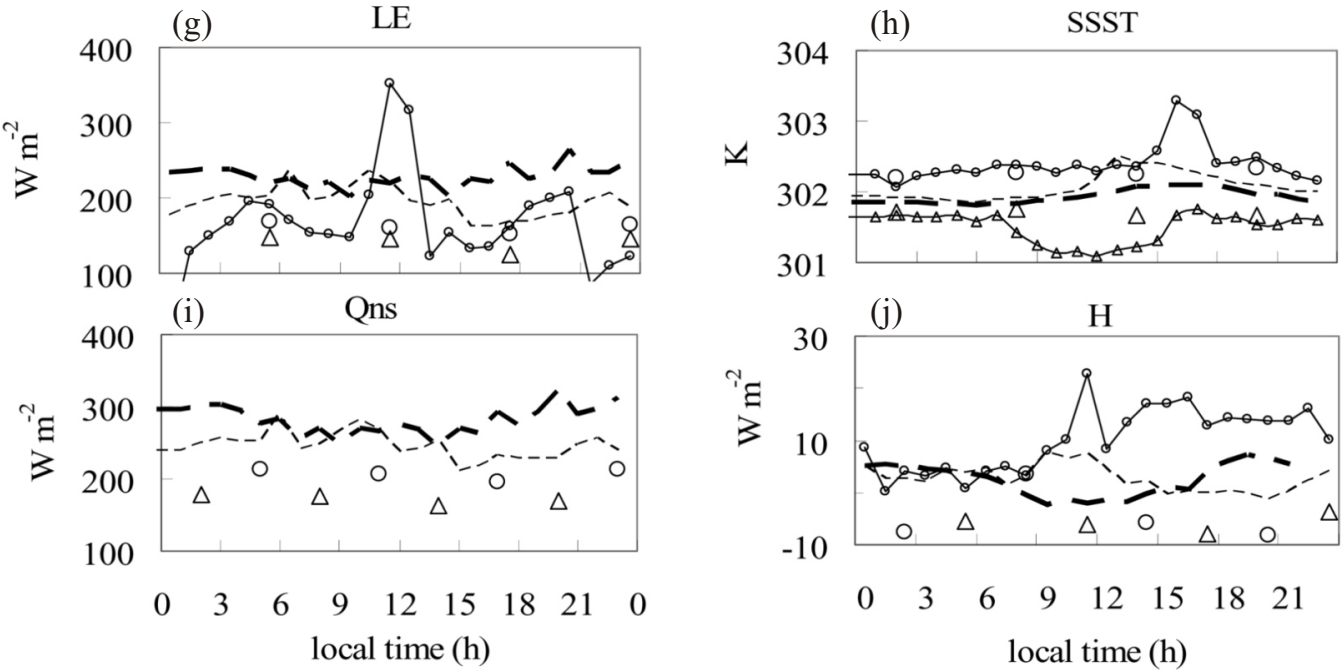

Fig. 7. Comparison of diurnal composites of meteorological variables and surface heat fluxes between model estimation (cal.) and NCEP2 during OR1-728 (2004) and OR1-802 (2006) cruises. The thin line contains triangle $(\triangle)$ is observed data in 2004; the thin line contains circle ( $\ominus$ ) is observed data in 2006; the thick broken line (- $)$ is model simulation in 2004; the thin broken line (- -$)$ is model simulation in 2006; triangle $(\triangle)$ is NCEP2 reanalysis in 2004 and circle $(\bigcirc)$ is NCEP2 reanalysis in 2006.

that observed latent heat flux and sensible heat flux over at around the equator in the Indian Ocean in the spring 1999 were at 137 and $17 \mathrm{~W} \mathrm{~m}^{-2}$, respectively. The magnitudes of latent and sensible heat fluxes were close to this study.

The friction velocity was lower than $0.1 \mathrm{~m} \mathrm{~s}^{-1}$ when wind speed was lower than $3 \mathrm{~m} \mathrm{~s}^{-1}$. Figure 8 shows that the friction velocity and latent heat flux both increased with wind speed, of which the correlation coefficient $(r)$ of wind speed with friction velocity is 0.5 , and with surface latent heat flux is 0.24 . This is reasonable since according to the similarity theory (Businger et al. 1971), friction velocity and turbulent heat fluxes (surface latent heat flux and surface sensible heat flux) should increase with wind speed under the conditions that the other variables remain unchanged. Subrahamanyam and Ramachandran (2002) also found that friction velocity and latent heat flux both increased with wind speed. Nonethe- 

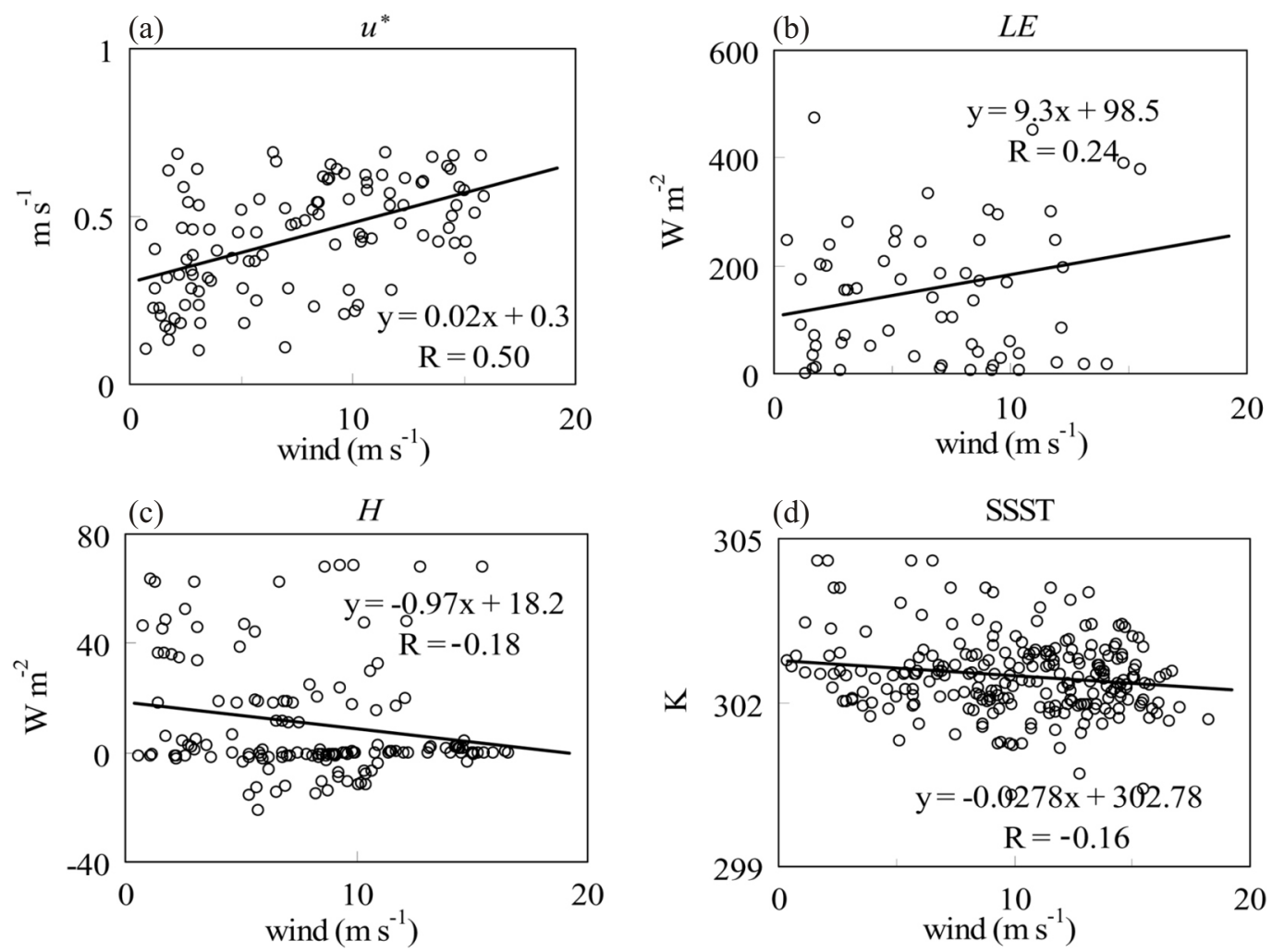

Fig. 8. Observed friction velocity $\left(u^{*}\right)$, surface latent heat flux $(L E)$, surface sensible heat flux $(H)$ and SSST as functions of wind speed during the 19 July to 2 August 2006 over the SCS (the OR1-802 cruise).

less, Fig. 8 also shows that the correlation coefficient of wind speed with surface sensible heat flux is -0.18 , and with SSST is -0.16 . This is likely due to that high wind speed caused higher upward latent heat flux. As a result, more energy was released into the atmosphere, and SSST decreased. Then, surface sensible heat flux decreased due to the decreased SSST.

The highest latent and sensible heat fluxes occurred at 10 am 26 July 2006, when the wind speed was as high as $10 \mathrm{~m} \mathrm{~s}^{-1}$ (Fig. 6). Surface latent flux was $630 \mathrm{~W} \mathrm{~m}^{-2}$ and surface sensible flux was $93 \mathrm{~W} \mathrm{~m}^{-2}$ at $10 \mathrm{am}$. On that day, wind speed was high $\left(>10 \mathrm{~m} \mathrm{~s}^{-1}\right)$, and both air temperature and specific humidity dropped by $3 \mathrm{~K}$ and $1.1 \mathrm{~g} \mathrm{~kg}^{-1}$, respectively, compared to the previous day (Fig. 4). Nonetheless, the SSST was about the same as the previous day. As a result, the largest turbulent heat fluxes were generated.

\subsection{Evaluation of the NCEP2 Data}

The meteorological variables observed during the cruises are close to those of the NCEP2 (Table 2 and Figs. 3, 4). The RMSDs between NCEP2 and observations were $0.8 \mathrm{~K}$ for air temperature during the second cruise, $1 \mathrm{~K}$ for SSST, $4 \mathrm{~m} \mathrm{~s}^{-1}$ for wind speed, about $1.2 \mathrm{~g} \mathrm{~kg}^{-1}$ for specific humidity during the first cruise and about $6 \mathrm{hPa}$ for atmospheric pressure. These differences are close to those reported over other oceans (Miller and Katsaros 1992; Hsu et al. 1997; Jones et al. 1999; Zong et al. 2007). However, NCEP2 systematically underestimates the wind speed by $1-2 \mathrm{~m} \mathrm{~s}^{-1}$ most of the time, overestimates atmospheric downward longwave radiation by $31 \mathrm{~W} \mathrm{~m}^{-2}$, and overestimates terrestrial upward longwave radiation by $20 \mathrm{~W} \mathrm{~m}^{-2}$.

The standard deviations (STD) of the most meteorological variables over the sea were small. Therefore, the normalized RMSD (i.e., RMSD/STD) of those variables were large $(0.4 \sim 3.3)$. It implies that although NCEP 2 correctly reproduces the magnitudes of the meteorological variables over the SCS, it is unable to reproduce the details of the fluctuations of these variables. Much larger diurnal fluctuations of air temperature, atmospheric pressure and wind speed were observed during the cruises than those reported in NCEP2 (Figs. 3, 4). Moore and Renfrew's (2002) comparison with in situ data shows the surface layer meteorological fields are reasonably well represented in the NCEPNCAR reanalysis. Besides, it was found that NCEP2 underestimated atmospheric pressure over the seas for locations near coast such as Vietnam and Pearl River Basin on 25, 26, and 30 August 2004 and 28 July 2006, which was likely due to the coarse resolution ( $\sim 1.875$ degree) of the land-sea mask of NCEP2.

The SSST of NCEP2 was close to observations with a 
Table 2. Comparisons between the results of NCEP2 reanalysis with observations.

\begin{tabular}{|c|c|c|c|c|c|c|c|c|}
\hline Variables & $\begin{array}{l}\text { Cruise } \\
\text { ID }\end{array}$ & no & NCEP2 & $\begin{array}{l}\text { Corr. } \\
\text { Coeff. }\end{array}$ & $\begin{array}{c}\text { Bias } \\
\text { (NCEP2-obs) }\end{array}$ & MAE & RMSD & NRMSD \\
\hline \multirow[t]{2}{*}{ 1. Air temperature $(\mathrm{K})$} & OR1-728 & 70 & $302 \pm 1$ & 0.34 & -0.9 & 1.1 & 1.5 & 1.4 \\
\hline & OR $1-802$ & 48 & $302 \pm 1$ & 0.17 & 0.1 & 0.6 & 0.8 & 1.4 \\
\hline \multirow[t]{2}{*}{ 2. Atmospheric pressure $(\mathrm{hPa})$} & OR $1-728$ & 70 & $1004 \pm 6$ & 0.54 & -2.5 & 3.4 & 6 & 2.3 \\
\hline & OR $1-802$ & 53 & $1006 \pm 5$ & 0.30 & -1.6 & 3.6 & 5 & 2.7 \\
\hline \multirow[t]{2}{*}{ 3. Specific humidity $\left(\mathrm{g} \mathrm{kg}^{-1}\right)$} & OR $1-728$ & 30 & $21 \pm 1$ & -0.05 & 1.2 & 1.3 & 1.2 & 1.2 \\
\hline & OR1-802 & 41 & $20 \pm 1$ & -0.22 & 1.0 & 6.1 & 6.9 & 1.0 \\
\hline \multirow[t]{2}{*}{ 4. Wind speed $\left(\mathrm{m} \mathrm{s}^{-1}\right)$} & OR1-728 & 70 & $9 \pm 4$ & 0.6 & -0.9 & 3.3 & 4 & 1.2 \\
\hline & OR1-802 & 55 & $7.3 \pm 3$ & 0.52 & -1.7 & 3.7 & 4 & 0.9 \\
\hline \multirow{2}{*}{$\begin{array}{l}\text { 5. Incoming solar radiation } \\
\left(\mathrm{W} \mathrm{m}^{-2}\right)\end{array}$} & OR $1-728$ & 70 & $199 \pm 228$ & 0.93 & -3 & 65 & 110 & 0.4 \\
\hline & OR1-802 & 55 & $230 \pm 262$ & 0.84 & 12 & 96 & 163 & 0.6 \\
\hline \multirow{2}{*}{$\begin{array}{l}\text { 6. Atmospheric longwave } \\
\text { radiation }\left(\mathrm{W} \mathrm{m}^{-2}\right)\end{array}$} & OR1-728 & 51 & $434 \pm 14$ & 0.23 & 31 & 27 & 27 & 2.5 \\
\hline & OR $1-802$ & 36 & $429 \pm 12$ & 0.32 & 31 & 31 & 27 & 3.0 \\
\hline \multirow{2}{*}{$\begin{array}{l}\text { 7. Terrestrial longwave radiation } \\
\left(\mathrm{W} \mathrm{m}^{-2}\right)\end{array}$} & OR1-728 & 58 & $470 \pm 4$ & 0.86 & 20 & 20 & 19 & 3.3 \\
\hline & OR1-802 & 52 & $473 \pm 4$ & 0.1 & 17 & 18 & 19 & 3.2 \\
\hline \multirow[t]{2}{*}{ 8. SSST (K) } & OR $1-728$ & 56 & $301.7 \pm 0.8$ & 0.74 & 0.2 & 0.5 & 0.6 & 0.7 \\
\hline & OR $1-802$ & 55 & $302.3 \pm 0.6$ & 0.11 & 0 & 0.7 & 0.9 & 1.2 \\
\hline 9. Friction velocity $\left(\mathrm{m} \mathrm{s}^{-1}\right)$ & OR1-802 & 24 & $0.2 \pm 0.1$ & 0.47 & -0.2 & 0.2 & 0.2 & 1.4 \\
\hline $\begin{array}{l}\text { 10. Surface sensible heat flux } \\
\left(\mathrm{W} \mathrm{m}^{-2}\right)\end{array}$ & OR1-802 & 22 & $3 \pm 5$ & 0.05 & 0 & 9 & 11 & 1.1 \\
\hline $\begin{array}{l}\text { 11. Surface latent heat flux } \\
\left(\mathrm{W} \mathrm{m}^{-2}\right)\end{array}$ & OR1-802 & 23 & $166 \pm 47$ & 0.45 & 12 & 67 & 82 & 0.9 \\
\hline
\end{tabular}

Note: Here, "no" denotes the valid numbers of 6 hourly data, "Corr. coeff." denotes correlation coefficient (r), "MAE" denotes mean absolute error, "RMSD" denotes root-mean-squared difference, and "NRMSD" denotes the normalized RMSD (i.e., RMSD/STD). Note that friction velocity, surface sensible heat flux and surface latent heat flux were observed only on ORI-802 cruise in 2006.

RMSD of $1 \mathrm{~K}$ and a correlation coefficient of 0.7 for OR1-728; for OR1-802 the RMSD was similar (0.9 K), but the correlation coefficient was 0.1 (Table 2 and Fig. 5).

The representative albedo during the two cruises was $0.07-0.08$ during daylight hours ( $10 \mathrm{am}-4 \mathrm{pm})$, close to the value of 0.06 at 1100 LT. used in NCEP2.

The bias and RMSD of the sensible heat flux between NCEP2 and observations are 0 and $11 \mathrm{~W} \mathrm{~m}^{-2}$, respectively, and those of the latent heat flux are 12 and $82 \mathrm{~W} \mathrm{~m}^{-2}$, respectively, during the second cruise. Sensible heat flux and latent heat fluxes at ocean surface are considerably different between the Data Assimilation Office (NASA/DAO) and NCEP reanalyses compared by Bony et al. (1997), they indicate that the two heat fluxes of NCEP are overestimated by 3 and $20 \mathrm{~W} \mathrm{~m}^{-2}$ than DAO, respectively. Their correlation coefficients were within $0.05-0.45$. The RMSD of the heat flux is close to the monthly RMSD within $2-10 \mathrm{~W} \mathrm{~m}^{-2}$ for the period 1993 - 1999 reported in Jo et al. (2004). Jo et al. (2004) calculated the sensible heat flux using satellite multi-sensor data. Moore and Renfrew (2002) also indicated that the surface latent heat flux on the North Atlantic and North Pacific Oceans from the NCEP-NCAR reanalysis is overestimated.

\subsection{Evaluation of the One-Column Ocean Model Results}

Figure 5 and Table 3 show comparisons of SSST, water temperatures at 4- and 10-m depths between observations and simulations. The simulated upper-level water temperatures (at 4 and $10 \mathrm{~m}$ depths) agree well with the observations during the two cruises (OR1-728, OR1-802) with a RMSD of smaller than $0.4 \mathrm{~K}$. The largest discrepancies were found on 17 and 26 August 2004 and 30 July 2006, when the water 
Table 3. Same as Table 2, but for comparisons of variables between observations (obs) and the results calculated by a one-column ocean model of Tu and Tsuang (2005) (cal), where "no" denotes the valid numbers of hourly data.

\begin{tabular}{|c|c|c|c|c|c|c|c|c|}
\hline Variables & $\begin{array}{l}\text { Cruise } \\
\text { ID }\end{array}$ & no & cal & $\begin{array}{l}\text { Corr. } \\
\text { coeff. }\end{array}$ & $\begin{array}{c}\text { Bias } \\
\text { (cal-obs) }\end{array}$ & MAE & RMSD & NRMSD \\
\hline \multirow[t]{2}{*}{ 1. Terrestrial longwave radiation $\left(\mathrm{W} \mathrm{m}^{-2}\right)$} & OR1-728 & 344 & $452 \pm 4$ & 0.31 & 1 & 4 & 6 & 1.1 \\
\hline & OR1-802 & 251 & $453 \pm 2$ & 0.51 & -4 & 4 & 6 & 1.1 \\
\hline \multirow[t]{2}{*}{ 2. Surface sensible heat flux $\left(\mathrm{W} \mathrm{m}^{-2}\right)$} & OR1-728 & 0 & $-12.6 \pm 19$ & - & - & - & - & - \\
\hline & OR1-802 & 126 & $5 \pm 14$ & 0.39 & 6 & 15 & 22 & 1.6 \\
\hline \multirow[t]{2}{*}{ 3. Surface latent heat flux $\left(\mathrm{W} \mathrm{m}^{-2}\right)$} & OR1-728 & 0 & $191 \pm 114$ & - & - & - & - & - \\
\hline & OR1-802 & 53 & $139 \pm 112$ & 0.32 & 20 & 116 & 150 & 1.4 \\
\hline 4. Friction velocity $\left(\mathrm{m} \mathrm{s}^{-1}\right)$ & OR1-802 & 96 & $0.3 \pm 0.2$ & 0.51 & -0.1 & 0.2 & 0.2 & 1.4 \\
\hline \multirow[t]{2}{*}{ 5. SSST (K) } & OR1-728 & 344 & $301.9 \pm 0.7$ & 0.54 & 0.4 & 0.7 & 0.8 & 0.8 \\
\hline & OR1-802 & 236 & $302.0 \pm 0.3$ & 0.57 & -0.4 & 0.6 & 0.8 & 0.9 \\
\hline \multirow[t]{2}{*}{ 6. 4-m depth water temp (K) } & OR $1-728$ & 37 & $301.8 \pm 0.5$ & 0.63 & 0.2 & 0.5 & 0.4 & 0.8 \\
\hline & OR1-802 & 18 & $302.1 \pm 0.2$ & 0.65 & 0.07 & 0.1 & 0.24 & 1.4 \\
\hline \multirow[t]{2}{*}{ 7. 10-m depth water temp (K) } & OR1-728 & 42 & $301.8 \pm 0.5$ & 0.81 & 0.08 & 0.4 & 0.26 & 0.5 \\
\hline & OR1-802 & 22 & $302.2 \pm 0.2$ & 0.72 & 0.06 & 0.1 & 0.2 & 1.3 \\
\hline
\end{tabular}

temperature changed significantly along the route. This is not unexpected, as the one-column ocean model assumes no-horizontal advection in the sea water.

Figure 9 shows the vertical profiles of simulated and observed water temperature on 23 and 27 July 2006. On 23 July, the wind speed was strong $\left(>9 \mathrm{~m} \mathrm{~s}^{-1}\right)$, but on $27 \mathrm{July}$, the wind speed was weak $\left(<5 \mathrm{~m} \mathrm{~s}^{-1}\right)$. Below the sea surface, sea water temperatures were measured by the CTD temperature sensor SBE 3plus, the accuracy of which was at $\pm 0.001 \mathrm{~K}$. The bias of temperatures between observation and simulation is within $0.1 \mathrm{~K}$ below sea surface. The simulated SST overestimates than observation about $0.13 \mathrm{~K}$ on 240023 July 2006. The error range is close to the model result of Shinoda and Hendon (1998). It can be seen that both the observed and simulated 4-m water temperatures (so called Bulk SST; BSST) did not show significant diurnal variation, with variation smaller than $0.5 \mathrm{~K}$. In contrast, significant diurnal variation was shown at SSST, with variation about $0.7 \mathrm{~K}$ when the wind was weak. It can be seen that the model suggests a warm layer existing within the depth from 0 to 4 meters during the day, and a cool skin existing within the top $1 \mathrm{~mm}$ during both day and night, which causes the SSST to be different from BSST observed at 4-m depth. Note that SSST is a very important factor for determining the air-sea exchanges of turbulent heat fluxes and tracer gases (e.g., $\mathrm{CO}_{2}$ ) (e.g., Weiss 1974; Wanninkhof et al. 1992). Incorporating a high vertical resolution model for upper sea temper- ature simulation such as that conducted in this study can be better than using BSST for this purpose. Webster et al. (1996) indicate that an error of $1 \mathrm{~K}$ in SSST can lead to an error of $27 \mathrm{~W} \mathrm{~m}^{-2}$ in net surface heat flux in the tropical western Pacific.

Figure 6 and Table 3 show comparisons of friction velocity, latent heat flux, sensible heat flux and terrestrial longwave radiation between observations and simulations. Their RMSDs are $0.2 \mathrm{~m} \mathrm{~s}^{-1}, 150,22$, and $4 \mathrm{~W} \mathrm{~m}^{-2}$, with correlation coefficients at $0.51,0.32,0.39$, and 0.57 , respectively, during the second cruise in 2006. The highest turbulent heat fluxes were observed on 26 July 2006, which are reproduced by the one-column ocean model (Fig. 6).

The correlation coefficient of simulated SSST with that of NCEP2 is 0.29 , and with observed air temperature is 0.52 (Table 4 and Fig. 5). The amplitude of the diurnal composite SSST is weak at $0.15 \mathrm{~K}$ when the wind speed is higher than $9 \mathrm{~m} \mathrm{~s}^{-1}$, but it becomes significant when wind speeds are low $\left(<5 \mathrm{~m} \mathrm{~s}^{-1}\right)$. For example, on 27 July 2006, when wind speeds were low, the calculated amplitude of SSST was $1.5 \mathrm{~K}$ and observed $3 \mathrm{~K}$ (Figs. 4, 5). This phenomenon is not seen in the NCEP2. A similar conclusion was noted by Kawai and Wada (2007), who show that diurnal SSST warming becomes evident when the surface wind is weak and insulation is strong. On 26 July 2006, both the observed air temperature and the SSST (derived for terrestrial longwave radiation measurement) dropped by $4 \mathrm{~K}$. 
This phenomenon was also not shown in NCEP2, but captured slightly by the model.

The correlation coefficient of the hourly latent heat flux estimations between the model simulation and observations is 0.3 with the RMSD at $150 \mathrm{~W} \mathrm{~m}^{-2}$ and the bias of $20 \mathrm{~W} \mathrm{~m}^{-2}$. The correlation coefficient of the hourly latent heat flux estimations between model estimation and NCEP2 is 0.21 in Table 4. Sea surface latent heat flux, one of the dominant components in the surface energy balance, plays a key role in the ocean and atmosphere (Peixoto and Oort 1992).

Table 4 shows the correlation matrix of variables such SSST, friction velocity, surface latent heat and surface sensible heat flux. It can be seen that the observations are more strongly correlated to the simulation by the one-column model, presented in this study, than they are to NCEP2. This implies that coupling a diurnal resolving ocean sub-model to a reanalysis model can be better than using prescribed SSST such as in current reanalysis.

\section{CONCLUSIONS}

The meteorological variables and surface energy components of the NCEP-DOE AMIP-II reanalysis over the South China Sea are found to compare reasonably with observation and observation-derived fluxes taken driving two research cruises in the summers of 2004 and 2006. A single column ocean model forced with the observation, are used to simulate the upper-level water temperature. The simulated upper-level water temperatures (at 4 and $10 \mathrm{~m}$ depths) of the two cruises agree well with available direct observations and NCEP2, with an RMSD smaller than $0.4 \mathrm{~K}$.

The major differences between the model estimate and the NCEP2 reanalysis are the value of emissivity and the inclusion of diurnal cycles in key variables. The NCEP2 value for emissivity is 1 , while the observed value is 0.96 with albedo at 0.07 . Nonetheless, NCEP2 systematically underestimates the wind speed by $1-2 \mathrm{~m} \mathrm{~s}^{-1}$ most of the time, overestimates atmospheric downward longwave radiation by $31 \mathrm{~W} \mathrm{~m}^{-2}$, and overestimates terrestrial upward longwave radiation by $20 \mathrm{~W} \mathrm{~m}^{-2}$.

Over the SCS, a diurnal cycle was observed in surface air temperature (OR1-728, OR1-802), sea surface temperature (OR1-728, OR1-802), terrestrial longwave radiation, atmospheric radiation, surface latent heat flux (OR1-728) and surface sensible heat flux (OR1-728). A semi-diurnal $(12 \mathrm{~h})$ was observed in sea surface pressure (OR1-728, OR1-802), surface specific humidity (OR1-728), and sensible heat flux (OR1-728). Sporadic high wind-speed periods were also observed during the cruises (Figs, 3, 4, 6, 7). The highest peak in sensible and latent heat flux occurred on 26 July 2006, causing the air temperature to drop rapidly. The average albedo of two cruises was $0.07-0.08$ between $10 \mathrm{am}$ and $4 \mathrm{pm}$. Both NCEP2 and the model simulation show that solar radiation is stronger than latent heat flux, and latent heat flux is stronger than sensible heat flux. Nonetheless, due to the sporadic wind speed observed in fluctuation meteorological variables, such as surface pressure and wind speed, high frequency also appear in the turbulent heat fluxes estimated by the model, which are not seen in the reanalysis.

A diurnal cycle is present in observed and simulated variables such as air temperature and SSST, but is not found in the NCEP2 (Fig. 7). As a result, fluxes in the NCEP2 are weaker than observed, thus it is important to incorporate the diurnal cycle in SSST in future reanalysis. The development of a diurnally resolved SSST data set is a current focus of research (Curry et al. 2004; Tu and Tsuang 2005; Clayson and Weitlich 2007; Kawai and Wada 2007).
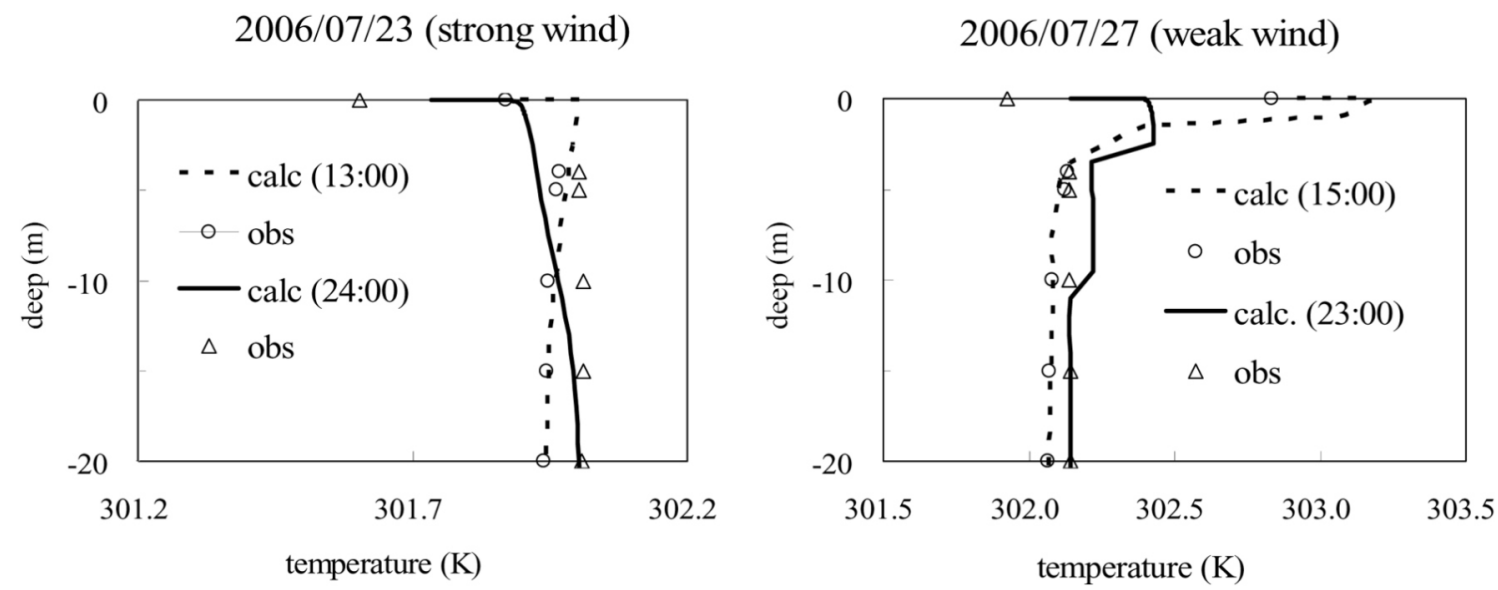

Fig. 9. The vertical profiles of simulated water temperatures compared with observation in cases of strong wind $\left(>9 \mathrm{~m} \mathrm{~s}^{-1}\right)$ and weak wind $\left(<5 \mathrm{~m} \mathrm{~s}^{-1}\right)$ over the South China Sea in 2006. The broken line (- -) is daytime model simulation; circle (O) is daytime observed data; the thick line (-) is nighttime model simulation, and triangle $(\triangle)$ is nighttime observed data. 
Table 4. Correlation matrix of variables including SST, friction velocity $\left(u^{*}\right)$, surface latent heat $(L E)$, and surface sensible heat flux $(H)(U n d e r l i n e d$ correlations are significant at $\mathrm{P}<5 \%$ ).

\begin{tabular}{lccccccc}
\hline Variables & SSST (cal) & SSST (NCEP) & SSST (obs) & BSST (cal) & $\boldsymbol{T}_{a}$ (obs) & $\boldsymbol{T}_{a}$ (NCEP) & $\boldsymbol{T}_{a}$ (obs2) \\
\hline SSST (cal) & 1 & $\underline{0.29}$ & $\underline{0.58}$ & $\underline{0.8}$ & $\underline{0.52}$ & $\underline{0.34}$ & $\underline{0.46}$ \\
SSST (NCEP) & 1 & $\underline{0.15}$ & $\underline{0.31}$ & $\underline{0.22}$ & $\underline{0.93}$ & 0.1 \\
SSST (obs) & & & 1 & $\underline{0.49}$ & $\underline{0.47}$ & $\underline{0.22}$ & $\underline{0.21}$ \\
BSST (cal) & & & & & $\underline{0.4}$ & $\underline{0.34}$ & $\underline{0.15}$ \\
$T_{a}$ (obs) & & & & & & $\underline{0.22}$ & $\underline{0.7}$ \\
$T_{a}$ (NCEP) & & & & & & 0.1 \\
$T_{a}$ (obs) & & & & & & & 1 \\
\hline
\end{tabular}

Note: $N=237$ (Casewise deletion of missing data).

\begin{tabular}{lccc}
\hline Variables & $\boldsymbol{u}^{*}$ (obs) & $\boldsymbol{u}^{*}(\mathrm{cal})$ & $\boldsymbol{u}^{*}$ (NCEP) \\
\hline$u^{*}(\mathrm{obs})$ & 1 & $\underline{0.48}$ & $\underline{0.44}$ \\
$u^{*}(\mathrm{cal})$ & & 1 & $\underline{0.34}$ \\
$u^{*}(\mathrm{NCEP})$ & & & 1 \\
\hline
\end{tabular}

Note: $N=107$ (raw data).

\begin{tabular}{lccc}
\hline Variables & $\boldsymbol{L E}(\mathbf{o b s})$ & $\boldsymbol{L E}(\mathrm{cal})$ & $\boldsymbol{L E}(\mathbf{N C E P})$ \\
\hline$L E(\mathrm{obs})$ & 1 & $\underline{0.32}$ & 0.22 \\
$L E(\mathrm{cal})$ & & 1 & 0.21 \\
$L E(\mathrm{NCEP})$ & & & 1 \\
\hline
\end{tabular}

Note: $N=53$ (raw data).

\begin{tabular}{lccc}
\hline Variables & $\boldsymbol{H}(\mathbf{o b s})$ & $\boldsymbol{H}(\mathbf{c a l})$ & $\boldsymbol{H}(\mathbf{N C E P})$ \\
\hline$H(\mathrm{obs})$ & 1 & $\underline{0.44}$ & 0.06 \\
$H(\mathrm{cal})$ & & 1 & 0.04 \\
$H(\mathrm{NCEP})$ & & & 1 \\
\hline
\end{tabular}

Note: $N=131$ (raw data).

Acknowledgements This study was financially supported by the National Science Council, Taiwan under the contracts: NSC 93-2621-Z-005-001, NSC 94-2621-Z-005005, NSC 95-2621-Z-005-004, NSC 95-2621-Z-110-005, NSC 96-2621-Z-005-002, and NSC 96-2621-Z-005-001. We would like to show our appreciation to Prof. J. Y. Luo and the crew of the R/V OR-1 for helping with our instrumentations during the cruise. The NCEP2 data are provided by the National Weather Service/Climate Prediction Center (http://nomad3.ncep.noaa.gov/ncep data/index. html). Thanks to C. H. McMillan, Dr. N. Keenlyside, and Dr. V. Yu for proofreading and to National Center for Ocean Research for providing the meteorology data and CTD data of R/V OR1. We are grateful to the National Cen- ter for High-performance Computing/Taiwan for computer time and facilities.

\section{REFERENCES}

Angelucci, M. G., N. Pinardi, and S. Castellari, 1998: Air-Sea Fluxes from operational analyses fields: Intercomparison between ECMWF and NCEP analyses over the Mediterranean area. Phys. Chem. Earth., 23, 569-574, doi: 10.1016/ S0079-1946(98)00071-8. [Link]

Artale, V., D. Iudicone, R. Santoleri, V. Rupolo, S. Marullo, and F. D'Ortenzio, 2002: Role of surface fluxes in ocean general circulation models using satellite sea surface temperature: Validation of and sensitivity to the forcing frequency 
of the Mediterranean thermohaline circulation. J. Geophys. Res., 107, 3120, doi: 10.1029/2000JC000452. [Link]

Blomquist, B. W., C. W. Fairall, B. J. Huebert, D. J. Kieber, and G. R. Westby, 2006: DMS sea-air transfer velocity: Direct measurements by eddy covariance and parameterization based on the NOAA/COARE gas transfer model. Geophys. Res. Lett., 33, L07601, doi: 10.1029/2006GL025735. [Link]

Bony, S., Y. Sud, K. M. Lau, J. Susskind, and S. Saha, 1997: Comparison and satellite assessment of NASA/DAO and NCEP-NCAR Reanalyses over Tropical Ocean: Atmospheric hydrology and radiation. J. Clim., 10, 1441-1462.

Bougeault, P. and P. Lacarrere, 1989: Parameterization of orography-induced turbulence in a Mesobeta-Scale Model. Mon. Weather Rev., 117, 1872-1890, doi: 10.1175/15200493(1989)117<1872:POOITI>2.0.CO;2. [Link]

Brutsaert, W. H., 1992: Stability correction functions for the mean wind-speed and temperature in the unstable surfacelayer. Geophys. Res. Lett., 19, 469-472.

Businger, J. A., J. C. Wyngaard, Y. Izumi, and E. F. Bradley, 1971: Flux-profile relationships in the atmospheric surface layer. J. Atmos. Sci., 28, 181-189, doi: 10.1175/1520-0469 (1971)028<0181:FPRITA>2.0.CO;2. [Link]

Chia, H. H. and C. C. Wu, 1998: Air-sea eddy fluxes and the mixed layer of the western equatorial pacific: Observation and one-dimensional model simulation. Atmos. Sci., 26, 157-179. (in Chinese)

Clayson, C. A. and D. Weitlich, 2007: Variability of tropical diurnal sea surface temperature. J. Climate, 20, 334-352.

Curry, J. A., A. Bentamy, M. A. Bourassa, D. Bourras, E. F. Bradley, M. Brunke, S. Castro, S. H. Chou, C. A. Clayson, W. J. Emery, L. Eymard, C. W. Fairall, M. Kubota, B. Lin, W. Perrie, R. A. Reeder, I. A. Renfrew, W. B. Rossow, J. Schulz, S. R. Smith, P. J. Webster, G. A. Wick, and X. Zeng, 2004: SEAFLUX. Bull. Amer. Meteorol. Soc., 85, 409-424.

Donlon, C. J., P. J. Minnett, C. Gentemann, T. J. Nightingale, I. J. Barton, B. Ward, and M. J. Murray, 2002: Toward improved validation of satellite sea surface skin temperature measurements for climate research. J. Climate, 15, 353369.

Edson, J. B., A. A. Hinton, K. E. Prada, J. E. Hare, and C. W. Fairall, 1998: Direct covariance flux estimates from mobile platforms at sea. J. Atmos. Ocean. Technol., 15, 547562.

Escoffier, C. and C. Provost, 1998: Surface forcing over the South West Atlantic according to NCEP and ECMWF reanalyses over the period 1979-1990. Phys. Chem. Earth, 23, 537-542, doi: 10.1016/S0079-1946(98)00067-6. [Link]

Fairall, C. W., E. F. Bradley, J. S. Godfrey, G. A. Wick, J. B. Edson, and G. S. Young, 1996: Cool-skin and warm-layer effects on sea surface temperature. J. Geophy. Res., 101, C1, 1295-1308, doi: 10.1029/95JC03190. [Link]

Feely, R. A., T. Takahashi, R. Wanninkhof, M. J. Mcphaden, C. E. Cosca, S. C. Sutherland, and M. E. Carr, 2006: Decadal variability of the air-sea $\mathrm{CO}_{2}$ fluxes in the equatorial Pacific Ocean. J. Geophy. Res., 111, C08S90, doi: 10.1029/ 2005JC003129. [Link]

Gaspar, P., Y. Gregoris, and J. M. Lefevre, 1990: A simple eddy kinetic energy model for simulations of the oceanic vertical mixing: Test at station Papa and long-term upper ocean study site. J. Geophy. Res., 95, 16179-16193, doi: 10.1029/JC095iC09p16179. [Link]

Grassl, H., 1976: The dependence of the measured cool skin of the ocean on wind stress and total heat flux. Bound.-Layer Meteor., 10, 465-474, doi: 10.1007/BF00225865. [Link]

Gregg, M. C., H. Peters, J. C. Wesson, N. S. Oakey, and T. J. Shay, 1985: Intensive measurements of turbulence and shear in the equatorial undercurrent. Nature, 318, 140-144, doi: 10.1038/318140a0. [Link]

Hasse, L., 1971: The sea surface temperature deviation and the heat flow at the sea-air interface. Bound.-Layer Meteor., 1 , 368-379, doi: 10.1007/BF02186037. [Link]

Hsu, C. S., M. G. Wurtele, G. F. Cunningham, and P. M. Woiceshyn, 1997: Construction of marine surface pressure fields from scatterometer wind alone. J. Appl. Meteorol., 36, 1249-1261, doi: 10.1175/1520-0450(1997)036<1249: COMSPF $>2.0 . \mathrm{CO} ; 2$. [Link]

Jilan, S., 2004: Overview of the South China Sea circulation and its influence on the coastal physical oceanography outside the Pearl River Estuary. Cont. Shelf Res., 24, $1745-$ 1760.

Jo, Y. H., X. H. Yan, J. Pan, W. T. Liu, and M. X. He, 2004: Sensible and latent heat flux in the tropical Pacific from satellite multi-sensor data. Remote Sens. Environ., 90, 166-177.

Jones, C., P. Peterson, C. Gautier, and C. Gautier, 1999: A new method for deriving ocean surface specific humidity and air temperature: An artificial neural network approach. $J$. Appl. Meteorol., 38, 1229-1245.

Kanamitsu, M., R. E. Kistler, and R. W. Reynolds, 1997: NCEP/NCAR reanalysis and the use of satellite data. $A d v$. Space Res., 19, 481-489, doi: 10.1016/S0273-1177(97) 00059-8. [Link]

Kanamitsu, M., W. Ebisuzaki, J. Woollen, S. K. Yang, J. J. Hnilo, M. Fiorino, and G. L. Potter, 2002: NCEP-DOE AMIP-II reanalysis (R-2). Bull. Amer. Meteorol. Soc., 83, 1631-1643, doi: 10.1175/BAMS-83-11-1631(2002)083 $<1631$ :NAR $>2.3 . \mathrm{CO} ; 2$. [Link]

Kawai, Y. and A. Wada, 2007: Diurnal sea surface temperature variation and its impact on atmosphere and ocean: A review. J. Oceanogr., 63 721-744, doi: 10.1007/s10872007-0063-0. [Link]

King, B. A., S. G. Alderson, and D. Cromwell, 1996: Enhancement of shipboard ADCP data with DGPS position and GPS heading measurements. Deep-Sea Res. I, 43, $937-$ 947, doi: 10.1016/0967-0637(96)00033-7. [Link]

Kowalski, A. S., 2001: Deliquescence induces eddy covariance and estimable dry deposition errors. Atmos. Environ., 35 , 4843-4851, doi: 10.1016/S1352-2310(01)00270-9. [Link]

Kraus, E. B. and J. A. Businger, 1994: Atmosphere-Ocean In- 
teraction, Oxford Univ. press, $2^{\text {nd }}$ edition, New York, $137-$ 180.

Lau, K. H., A. Y. Wang, Y. H. Kuo, S. J. Chen, and J. Dudhia, 1998: The evolution of the East Asia summer monsoon in June 1994: A numerical simulation. J. Meteorol. Soc. Jpn., 76, 749-764.

Leredde, Y., J. L. Devenon, and I. Dekeyser, 1999: Turbulent viscosity optimized by data assimilation. Ann. Geophys., 17, 1463-1477.

Lester, A. and D. R. Myers, 2006: A method for improving global pyranometer measurements by modeling responsivity functions. Sol. Energy, 80, 322-331, doi: 10.1016/ j.solener.2005.02.010. [Link]

Li, Z. X., 2001: Thermodynamic air-sea interactions and tropical Atlantic SST dipole pattern. Phys. Chem. Earth. (B), 26, 155-157, doi: 10.1016/S1464-1909(00)00233-1. [Link]

Lin, P. H., M. D. Chou, Q. Ji, and S. C. Tasy, 2002: Clear-sky surface solar radiation during the South China Sea monsoon experiment. Terr. Atmos. Ocean. Sci., 13, 185-195.

Locarnini, R. A., A. V. Mishonov, J. I. Antonov, T. P. Boyer, and H. E. Garcia, 2006: World Ocean Atlas 2005, Volume 1: Temperature. Levitus, S., (Ed.), NOAA Atlas NESDIS 61, US Government Printing Office, Washington, D.C., 182 pp.

Martin, P. J., 1985: Simulation of the mixed layer at OWS November and Papa with several models. J. Geophy. Res., 90, C1, 903-916, doi: 10.1029/JC090iC01p00903. [Link]

McGillis, W. R., J. B. Edson, J. E. Hare, and C. W. Fairall, 2001: Direct covariance air-sea $\mathrm{CO}_{2}$ fluxes. J. Geophy. Res., 106, C8, 16729-16745.

McGillis, W. R., J. B. Edson, C. J. Zappa, J. D. Ware, S. P. McKenna, E. A. Terray, J. E. Hare, C. W. Fairall, W. Drennan, M. Donelan, M. D. DeGrandpre, R. Wanninkhof, and R. A. Feely, 2004: Air-sea $\mathrm{CO}_{2}$ exchange in the equatorial Pacific. J. Geophy. Res., 109, C08S02, doi: 10.1029/ 2003JC002256. [Link]

Mckinley, G. A., T. Takahashi, E. Buitenhuis, F. Chai, J. R. Christian, S. C. Doney, M. S. Jiang, K. Lindasy, J. K. Moore, C. Le Quere, I. Lima, R. Murtugudde, L. Shi, and P. Wetzel, 2006: North Pacific carbon cycle response to climate variability on seasonal to decadal timescales. $J$. Geophy. Res., 111, C07S06, doi: 10.1029/2005JC003173. [Link]

Mellor, G. L. and P. A. Durbin, 1975: The structure and dynamics of the ocean surface mixed layer. J. Phys. Oceanogr., 5, 718-728, doi: 10.1175/1520-0485(1975) 005<0718:TSADOT>2.0.CO;2. [Link]

Mellor, G. L. and T. Yamada, 1982: Development of a turbulence closure model for geophysical fluid problems. Rev. Geophys. Space Phys., 20, 851-875, doi: 10.1029/RG020 i004p00851. [Link]

Midorikawa, T., M. Ishii, K. Nemoto, H. Kamiya, A. Nakadate, S. Masuda, H. Matsueda, T. Nakano, and H. Y. Inoue, 2006: Interannual variability of winter oceanic $\mathrm{CO}_{2}$ and air-sea $\mathrm{CO}_{2}$ flux in the western North Pacific for 2 decades. $J$.
Geophy. Res., 111, C08S19, doi: 10.1029/2005JC003095. Miller, D. K. and K. B. Katsaros, 1992: Satellite-derived surface latent heat fluxes in a rapidly intensifying marine cyclone. Mon. Weather Rev., 120, 1093-1107, doi: 10.1175/ 1520-0493(1992)120<1093:SDSLHF>2.0.CO;2. [Link]

Moore, G. W. K. and I. A. Renfrew, 2002: An assessment of the surface turbulent heat fluxes from the NCEP-NCAR reanalysis over the western boundary currents. J. Climate, 15, 2020-2037, doi: 10.1175/1520-0442(2002)015<2020: AAOTST $>2.0 . C O ; 2$. [Link]

Morton, B. and G. Blackmore, 2001: South China Sea. Mar. Pollut. Bull., 42, 1236-1263, doi: 10.1016/S0025-326X (01)00240-5. [Link]

Park, G. H., K. Lee, R. Wanninkhof, and R. A. Feely, 2006: Empirical temperature-based estimates of variability in the oceanic uptake of $\mathrm{CO}_{2}$ over the past 2 decades. $J$. Geophy. Res., 111, C07S07, doi: 10.1029/2005JC003090. [Link]

Paulson, C. A. and J. J. Simpson, 1981: The temperature difference across the cool skin of the ocean. J. Geophy. Res., 86, C11, 11044-11054.

Payne, R. E., 1972: Albedo of the sea surface. J. Atmos. Sci., 29, 959-969.

Peixoto, J. P. and A. H. Oort, 1992: Physics of Climate, Springer, New York, $520 \mathrm{pp}$.

Peters, H., M. C. Gregg, and J. M. Toole, 1988: On the parameterization of equatorial turbulence. J. Geophys. Res., 93, C2, 1199-1218.

Pinazo, C., P. Marsaleix, B. Millet, C. Estournel, and R. Vehil, 1996: Spatial and temporal variability of phytoplankton biomass in upwelling areas of the northwestern Mediterranean: A coupled physical and biogeochemical modelling approach. J. Mar. Syst., 7, 161-191, doi: 10.1016/ 0924-7963(95)00028-3. [Link]

Rozwadowska, A., 2004: Optical thickness of stratiform clouds over the Baltic inferred from on-board irradiance measurements. Atmos. Res., 72, 129-147, doi: 10.1016/j.atmosres. 2004.03.012. [Link]

Shiau, L. J., P. S. Yu, K. Y. Wei, M. Yamamoto, T. Q. Lee, E. F. Yu, T. H. Fang, and M. T. Chen, 2008: Sea surface temperature, productivity, and terrestrial flux variations of the southeastern South China Sea over the past 800000 years (IMAGES MD972142). Terr. Atmos. Ocean. Sci., 19, $363-$ 376, doi: 10.3319/TAO.2008.19.4.363(IMAGES). [Link]

Shinoda, T. and H. H. Hendon, 1998: Mixed layer modeling of intraseasonal variability in the tropical Western Pacific and Indian Oceans. J. Climate, 11, 2668-2685.

Simmons, A. J. and J. K. Gibson, 2000: The ERA40 Project Plan, ERA-40 Proj. Rep. Ser. 1, 63 pp, Eur. Cent. for Medium-Range Weather Forecasts, Reading, UK.

Soloviev, A. V. and P. Schlussel, 1996: Evolution of cool skin and direct air-sea gas transfer coefficient during daytime. Bound.-Layer Meteor., 77, 45-68, doi: 10.1007/BF0012 1858. [Link]

Subrahamanyam, D. B. and R. Ramachandran, 2002: Air-sea 
interface fluxes over the Indian Ocean during INDOEX, IFP-99. J. Atmos. Sol.-Terr. Phys., 64, 291-305, doi: 10.1016/S1364-6826(01)00091-8. [Link]

Tsuang, B. J., M. D. Chou, Y. Zhang, A. Roesch, and K. Yang, 2008a: Evaluations of land-ocean skin temperatures of the ISCCP satellite retrievals and the NCEP and ERA reanalyses. J. Climate, 21, 308-330, doi: 10.1175/2007 JCLI1502.1. [Link]

Tsuang, B. J., C. Y. Tu, J. L. Tsai, J. A. Dracup, K. Arpe, and T. Meyers, 2008b: A more accurate scheme for calculating Earth's skin temperature. Climate Dyn., 32, 251-272, doi: 10.1007/s00382-008-0479-2. [Link]

Tu, C. Y. and B. J. Tsuang, 2005: Cool-skin simulation by a one-column ocean model. Geophys. Res. Lett., 32, L22602, doi: 10.1029/2005GL024252. [Link]

Uu, D. V. and J. M. Brankart, 1997: Seasonal variation of temperature and salinity fields and water masses in the Bien Dong (South China) Sea. Mathl. Comput. Modelling, 26, 97-113, doi: 10.1016/S0895-7177(97)00243-4. [Link]

Wang, B., L. Ho, Y. Zhang, and M. M. Lu, 2004: Definition of South China Sea monsoon onset and commencement of the East Asia summer monsoon. J. Climate, 17, 699-710.

Wang, Y. H., S. Jan, and D. P. Wang, 2003: Transports and tidal current estimates in the Taiwan Strait from shipboard ADCP observations (1999-2001). Estuar. Coast. Shelf Sci., 57, 193-199, doi: 10.1016/S0272-7714(02)00344-X. [Link]

Wanninkhof, R., 1992: Relationship Between wind speed and gas exchange over the ocean. J. Geophy. Res., 97, C5, 7373-7382.

Wanninkhof, R., K. F. Sullivan, and Z. Top, 2004: Air-sea gas transfer in the Southern Ocean. J. Geophy. Res., 109,
C08S19, doi: 10.1029/2003JC001767. [Link]

Webster, P. J., C. A. Clayson, and J. A. Curry, 1996: Clouds, radiation, and the diurnal cycle of sea surface temperature in the tropical western Pacific. J. Climate, 9, 1712-1730.

Weiss, R. F., 1974: Carbon dioxide in water and seawater: The solubility of a non-ideal gas. Mar. Chem., 2, 203-215, doi: 10.1016/0304-4203(74)90015-2. [Link]

Wilber, A. C., D. P. Kratz, and S. K. Gupta, 1999: Surface emissivity maps for use in satellite retrievals of longwave radiation. NASA Tech. Publication TP-1999-209362, 35 pp. [Link]

Wilczak, J. M., S. P. Oncley, and S. A. Stage, 2001: Sonic anemometer tilt correction algorithms. Bound-Layer Meteor., 99, 127-150, doi: 10.1023/A:1018966204465. [Link]

Wu, J., 1985: On the cool skin of the ocean. Bound.-Layer Meteor., 31, 203-207, doi: 10.1007/BF00121179. [Link]

Zhang, Y. and T. Li, 2008: Influence of the sea surface temperature in the Indian Ocean on the in-phase transition between the South Asian and North Australian summer monsoons. Terr. Atmos. Ocean. Sci., 19, 321-329, doi: 10.3319/TAO. 2008.19.3.321(A). [Link]

Zhang, Y., W. B. Rossow, A. A. Lacis, V. Oinas, and M. I. Mishchenko, 2004: Calculation of radiative fluxes from the surface to top of atmosphere based on ISCCP and other global data sets: Refinements of the radiative transfer model and the input data. J. Geophys. Res., 109, D19105, doi: 10.1029/2003JD004457. [Link]

Zong, H., Y. Liu, Z. Rong, and Y. Cheng, 2007: Retrieval of sea surface specific humidity based on AMSR-E satellite data. Deep-Sea Res. I, 54, 1189-1195, doi: 10.1016/j.dsr.2007. 04.008. [Link] 